\title{
EFECTOS DE LAS SENTENCIAS ANULATORIAS DE NORMAS EN EL ÁMBITO TRIBUTARIO (*)
}

\author{
Begoña Sesma Sánchez \\ Catedrática de Derecho Financiero y Tributario \\ Universidad de Oviedo \\ ORCID: 0000-0002-5566-9882
}

Recibido: Octubre, 2020.

Aceptado: Noviembre, 2020.

https://dx.doi.org/10.47092/CT.20.4.6

\section{RESUMEN}

El trabajo analiza los efectos derivados de sentencias que invalidan normas tributarias por inconstitucionalidad, infracción de derecho europeo o ilegalidad a partir de la jurisprudencia más reciente. Se examina el margen de los distintos órganos jurisdiccionales para fijar el alcance material y temporal de sus pronunciamientos de invalidez de normas, así como la incidencia de la causa de invalidez para ponderar los efectos. Se concluye con un examen de las posibilidades de revisión de los actos firmes tributarios dictados al amparo de normas inválidas.

Palabras clave: Inconstitucionalidad, ilegalidad, infracción de derecho europeo, normas tributarias, sentencias anulatorias, efectos.

${ }^{*}$ ) Este trabajo forma parte de los resultados del Proyecto de Investigación "Reformas recientes y pendientes del sistema tributario español en un contexto de descentralización", Referencia MINECO-18-DER2017-83703-P. 


\title{
EFFECTS OF JUDGMENTS ANNULLING REGULATIONS IN THE FIELD OF TAXATION
}

Begoña Sesma Sánchez

\begin{abstract}
The work analyzes, based on the most recent jurisprudence, the effects derived from sentences that invalidate tax rules due to unconstitutionality, infringement of European law or illegality. It examines the margin of the different courts to delimit the material and temporal scope of their judgements of invalidity of rules, as well as the incidence of the cause of invalidity to weigh the effects. It concludes with an examination of the possibilities of reviewing final acts issued under invalid rules.
\end{abstract}

Keywords: Unconstituonality, illegality, infringement of European law, tax rules, judgements, effects 


\section{SUMARIO}

1. INTRODUCCIÓN. 2. LA INVALIDEZ DE LAS NORMAS TRIBUTARIAS: PREMISAS GENERALES. 3. EFECTOS DERIVADOS DE LAS SENTENCIAS ANULATORIAS DE NORMAS TRIBUTARIAS. 3.1. Efectos derivados de pronunciamientos de inconstitucionalidad. 3.2. Efectos derivados de declaraciones de ilegalidad de normas reglamentarias o disposiciones generales. 3.3. Efectos derivados de declaraciones de infracción del derecho europeo. 4. Alternativas DE REvisión DE LOS ACTOS TRIBUTARIOS DICTADOS AL AMPARO DE NORMAS INVÁLIDAS. 4.1. La acción de nulidad de pleno derecho. 4.2. La revocación de actos firmes dictados al amparo de una norma inválida. 4.3. La devolución de ingresos indebidos. 4.4. El recurso extraordinario de revisión. 5. La ReSponsabilidad Patrimonial del Estado legislador o DE LA AdMinistración POR LA APROBACIÓN DE NORMAS INVÁLIDAS. BIBLIOGRAFÍA.

\section{INTRODUCCIÓN}

¿En el ámbito tributario producen los mismos efectos la sentencia de inconstitucionalidad, la que declara la infracción del derecho europeo o la ilegalidad de una norma reglamentaria? ¿Dependen los efectos de la causa de invalidez de la norma? ¿Tienen los órganos jurisdiccionales competencia o margen para delimitar el alcance temporal de sus declaraciones de invalidez? ¿Cabe la revisión de un acto tributario firme dictado al amparo de una norma inválida? ¿Y la responsabilidad del Estado o de la Administración por haber aprobado una norma inválida?

A pesar de los frecuentes ejemplos de invalidez de normas tributarias -entre los más recientes, la inconstitucionalidad parcial de la plusvalía y de los pagos fraccionados en el Impuesto sobre Sociedades (en adelante, IS), la infracción del derecho europeo de las normas de tributación de los no residentes en el Impuesto sobre Sucesiones y Donaciones (en adelante, ISD), la ilegalidad de preceptos reglamentarios del Reglamento del Impuesto sobre el Valor Añadido (en adelante, RIVA) o de varias ordenanzas fiscales-, no existen respuestas claras ni pacíficas a aquellas cuestiones. Nuestro ordenamiento carece de una regla común para fijar los efectos derivados de las sentencias que declaran la invalidez de una norma, sea tributaria o no. En su lugar existen, como se expondrá seguidamente, preceptos dispersos en distintas normas (art. 40 LOTC, 73 LJCA, 106.4 LPAC, 19.2 TRLRHL) que, en unos casos, determinan la nulidad de la norma declarada inconstitucional o ilegal -pero sin abordar la cuestión de qué sucede con los actos firmes afectados por ella-; en otros se refieren a la nulidad de pleno derecho de la norma reglamentaria ilegal dejando expresamente subsistentes los actos firmes afectados por la norma inválida (art. 73 LJCA) y en otros reconocen más o menos explícitamente potestad a los órganos jurisdiccionales para fijar el alcance de sus fallos, en ocasiones, con un amplio margen de libertad (art. 19.2 TRLRLHL, art. 32 LRJSP). Tampoco existen reglas generales que permitan modular los efectos de una sentencia anulatoria en función de la naturaleza formal (rango o procedimiento de aprobación de la norma inválida) o material (contenido inválido de su regulación) de la causa de invalidez o de su gravedad o entidad. Y, en fin, tampoco está regulada de forma equivalente la posible responsabilidad 
patrimonial del Estado legislador por haber aprobado y aplicado una norma inconstitucional o contraria al Derecho de la Unión Europea (art. 32 LRJSP), ni la posible responsabilidad de la Administración por haber aprobado y aplicado una disposición general ilegal (art. 106.4 LPAC).

Sin embargo, desde la perspectiva de los obligados tributarios que han satisfecho un "tributo ilegal" o "soportado" la aplicación de una norma tributaria inicialmente válida, pero posteriormente anulada, se persigue con esfuerzo la búsqueda de la justicia material del caso, esto es, la recuperación de lo pagado "ilegal o injustamente" al amparo de una norma "inválida" (1). Y en esa búsqueda de la "justicia material" se "fuerzan" en ocasiones las reglas y requisitos de los sistemas de revisión de los actos tributarios. Así, por ejemplo, se invoca como dogma iuris et de iure, la invalidez retroactiva de lo actuado o la nulidad radical de la liquidación firme por invalidez sobrevenida, se insta la rectificación de la autoliquidación computando la prescripción desde que se declaró la invalidez de la norma que la amparaba, se defiende el "deber" de la Administración de proceder a la revocación del acto, se invoca la sentencia anulatoria a los efectos de promover un recurso extraordinario de revisión o, en fin, subsidiariamente se reclama la responsabilidad patrimonial del Estado legislador o de la Administración por haber dictado y/o aplicado una norma inválida (2).

En la medida en que algunas de estas cuestiones han sido objeto de pronunciamientos jurisprudenciales recientes y relevantes y, en algún caso contradictorios, particularmente del Tribunal Supremo (en adelante, TS), el propósito de este trabajo es exponer el marco general que regula los efectos derivados de la declaración de invalidez de las normas en el ámbito tributario (epígrafe 2), analizando en cada caso qué margen tienen los órganos jurisdiccionales para modular los efectos de sus fallos en los supuestos de inconstitucionalidad, infracción del derecho europeo e ilegalidad de las normas reglamentarias (epígrafe 3) y examinar los sistemas de revisión al alcance de los obligados tributarios para hacer valer esa invalidez respecto de actos firmes (epígrafe 4).

\section{LA INVALIDEZ DE LAS NORMAS TRIBUTARIAS: PREMISAS GENERALES}

La presunta y tradicional concepción de las normas tributarias materiales como restrictivas de derechos (3), ha alentado con frecuencia una importante litigiosidad normativa. Una

(1) En ocasiones incurriendo en actitudes contradictorias porque, dicho en términos coloquiales, el mismo contribuyente que defiende con tesón la validez de su licencia urbanística concedida al amparo de un plan urbanístico anulado es el mismo que reclama la nulidad de la liquidación del IBI o de la plusvalía por el mismo motivo.

(2) Sobre la nulidad de las liquidaciones tributarias -acto tributario paradigmático por excelencia- por invalidez de la norma de cobertura vid., con más detalle, Sesma Sánchez (2017).

(3) El presente trabajo se centra en el análisis de los efectos de la declaración de invalidez de normas tributarias de contenido material, esto es, referidas al establecimiento o cuantificación de obligaciones tributarias, ya fuera "formal" la causa de su invalidez (por ejemplo, la recién declarada inconstitucionalidad del RDL 2/2016, relativo a los pagos fraccionados en el Impuesto sobre Sociedades por la improcedencia de utilizar el Decreto-Ley para regular esta materia, STC 78/2020, de 1 de julio), ya fuera "material" el motivo de su invalidez (como ha sucedido con las declaraciones 
gran mayoría de leyes o normas tributarias con rango de Ley -dada la profusión reciente de Decretos-Leyes en esta materia- que establecen ex novo un tributo, o incrementan la cuota tributaria, son recurridas directa (recurso de inconstitucionalidad) o indirectamente (cuestión de inconstitucionalidad) ante el Tribunal Constitucional (en adelante, TC), o bien, en tanto que interfieran en el derecho europeo, son examinadas por el Tribunal de Justicia de la Unión Europea (en adelante, TJUE), o bien, tratándose de disposiciones generales impugnadas, directa o indirectamente ante los órganos jurisdiccionales contencioso-administrativos. No es infrecuente, incluso, encontrar impugnaciones simultáneas de la misma norma tributaria ante el TC y el TJUE con el consiguiente conflicto que se deriva de todo "diálogo entre Tribunales" no solo por la "competencia" entre jurisdicciones, sino por la incompleta regulación de la litispendencia y prejudicialidad en nuestro sistema jurisdiccional y, en general, de la suspensión de procesos (art. 33 LJCA y 43 LEC) mientras se dirime la validez (constitucional y europea) de la norma. La situación actual del Impuesto sobre el Valor de la Producción de la Energía Eléctrica (IVPEE), cuestionado en sede constitucional, europea y contenciosa casi simultáneamente es un buen ejemplo de la complejidad que implica el conocimiento síncrono por distintos Tribunales de la misma norma (4). También se da este tipo de conflictos en el enjuiciamiento simultáneo de recursos directos contra actos administrativos "generales" cuasi reglamentarios (por ejemplo, ponencias de valores) o disposiciones reglamentarias (por ejemplo, planes urbanísticos) y los indirectos contra los actos dictados en aplicación de ellas (las liquidaciones del IBI o del IIVTNU) o incluso, como ha sucedido con las normas forales fiscales vascas, cuando se ha simultaneado su revisión casacional por el TS en tanto que normas reglamentarias antes de la aprobación de la Ley Orgánica 1/2010, de 19 de febrero, y su enjuiciamiento constitucional tras la entrada en vigor de dicha norma (5), supuestos

de inconstitucionalidad de la plusvalía por contravenir el principio de capacidad económica -por todas, la STC 59/2017, de 11 de mayo-). Quedan al margen de nuestro estudio, por tanto, la invalidez de normas tributarias de contenido formal o procedimental como pudieran ser, por citar ejemplos recientes, la inconstitucionalidad parcial del código tributario catalán (STC 65/2020, de 18 de junio), la ilegalidad del apartado 2 del artículo 197.bis del RGGI (STS de 25 de septiembre de 2019, rec. 85/2018, ECLI: ES:TS:2019:3146) o la anulación del Reglamento del IVA respecto de la baja en el registro de devolución mensual y renuncia extraordinaria a la aplicación del régimen especial del grupo de entidades, por haberse aprobado la modificación reglamentaria sin el preceptivo dictamen del Consejo de Estado (STS de 5 de julio de 2019, rec. 535/2017, ECLI:ES:TS:2019:2351). No obstante, a mi juicio, procede advertir que también en estos casos de invalidez de una norma que regula cuestiones de forma o de procedimiento, si la anulación de la norma hubiera generado perjuicios o daños "antijurídicos" estaría legitimada la reclamación de responsabilidad patrimonial si concurren los requisitos de esta figura (efectividad del daño, causalidad y carácter antijurídico).

(4) No procede ahora detallar la tortuosa revisión jurisdiccional del IVPEE. Baste apuntar que mientras se inadmitían por el TC diversas cuestiones de inconstitucionalidad (ATC 202 y 204/2018, de 13 de diciembre, 69/2018, de 20 de junio y 118/2018, de 30 de octubre), en ese impasse, el TSJ de Valencia elevó una cuestión prejudicial ante el TJUE lo que ha provocado que, a pesar de la escasa aplicación que tiene en nuestro sistema jurisdiccional contencioso-administrativo el artículo 43 LEC, referido a la suspensión de las actuaciones judiciales hasta que se resuelva una cuestión prejudicial, el TS haya acordado la suspensión del proceso de enjuiciamiento del IVPEE hasta que el TJUE resuelva la cuestión prejudicial planteada. Al respecto vid., Alonso García y Almudí Cid (2020).

(5) A raíz de esta controversia el propio TS ha tenido que resolver si la inconstitucionalidad de las normas forales fiscales vascas (STC 203/2016, de 1 de diciembre) y la ilegalidad (por incons- 
todos ellos que provocan un elevando riesgo de pronunciamientos contradictorios y originan no pocos problemas de ejecución. Desde luego, y esta es una observación que meramente se apunta, creo que es tiempo de mejorar la escueta regulación de los supuestos de suspensión del proceso jurisdiccional cuando simultáneamente se enjuicia la validez de la norma así como la regulación procesal de la litispendencia y prejudicialidad contencioso-administrativa singularmente en ciertos casos (por ejemplo, cuando existe un amplio número de recursos similares afectados por una cuestión que se va a dirimir en sede casacional) (6).

También es una evidencia que en los últimos años se han incrementado las cuestiones tributarias sometidas al examen de la jurisdicción europea. Si bien esta realidad seguramente responde a la mayor facilidad de acceso de los asuntos al TJUE -frente a la dificultad de acceder en amparo ante el TC o de promover cuestiones de inconstitucionalidad- y a la mayor rapidez de sus pronunciamientos (7), contribuyendo así a "entronizar" al derecho europeo como parámetro de control de la legislación tributaria nacional -especialmente su contenido principialista-, lo cierto es que la revisión europea de las normas tributarias nacionales arroja, a mi juicio, una importante dosis de inseguridad jurídica. El TJUE determina con amplia libertad y dispar criterio los efectos de sus fallos, que tanto pueden suplantar de facto al juez nacional en su competencia exclusiva para resolver el litigio, como "devolver la pelota" y dejar en manos de los órganos jurisdiccionales nacionales la interpretación de compatibilidad con el Derecho de la Unión la norma controvertida a la vista de su sentencia (8).

titucionalidad) de las mismas, declarada también por el TS (STS de 23 de octubre de 2014, rec. 230/2012, ECLI:ES:TS:2014:4976) habilitaba la vía de la responsabilidad patrimonial del Estado legislador o, por el contrario, la de la Administración. Y la decisión del TS ha sido que «tras la entrada en vigor de la LO 1/2020, las normas fiscales forales del País Vasco, en la medida en que sólo pueden declararse inconstitucionales y solo por el Tribunal Constitucional, dicha declaración abre la vía de resarcimiento de los daños y perjuicios ocasionados por la vía de la responsabilidad patrimonial del Estado legislador. Sin embargo, las declaraciones necesariamente, de nulidad realizadas por los Tribunales de lo Contencioso-Administrativo, antes de la entrada en vigor de dicha Ley Orgánica -procesos iniciados con anterioridad a la misma-, quedan sometidos al régimen de responsabilidad de las Administraciones públicas», vid., STS de 24 de junio de 2020, rec. 2245/2019, ECLI:ES:TS:2020:2208.

(6) El propio TS ha reclamado en la Memoria de su actividad judicial del año 2019 una reforma de la LJCA que permita resolver la reiteración de recursos casacionales sobre la misma cuestión controvertida, o sustancialmente similar en cuanto al fondo, vid., http://www.poderjudicial. es/cgpj/es/Poder-Judicial/Tribunal-Supremo/Actividad-del-TS/Memoria-del-TS/Memoria-2019TRIBUNAL-SUPREMO, p. 54, [consultado el 8/10/2020].

(7) Es notoria la relevancia de la jurisprudencia europea en la interpretación de la legislación tributaria nacional, particularmente en el ámbito del IVA, de los IIEE y de aquellos tributos que tienen una incidencia directa en la libre circulación de personas y bienes, al margen de los pronunciamientos también frecuentes en materia de ayudas de Estado de carácter fiscal. Baste recordar, a título de ejemplo, las STJUE de 6 de octubre de 2005 (C-204/03) y de 16 de enero de 2010 (C118/08) referidas a la tributación de las subvenciones en el IVA, la STJUE de 6 de octubre de 2009 (C-562/07) relativa a la tributación de las ganancias patrimoniales de residentes y no residentes, la STJUE de 27 de febrero de 2014 (C-82/12) con relación al llamado "céntimo sanitario" o las SSTJUE de 26 de abril de 2018 (asuntos C-236/16 y 237/16) respecto de los tributos autonómicos catalán, asturiano y aragonés sobre las grandes superficies comerciales.

(8) Conforme a los informes anuales de la actividad judicial del TJUE, España ocupa el tercer 
En fin, también las normas reglamentarias tributarias (y, en particular, las ordenanzas fiscales) o con repercusiones tributarias (como sucede con los planes generales de ordenación urbana) son recurridas directa o indirectamente (a través de la impugnación del acto) con el argumento, en la mayoría de las ocasiones, de incurrir en un exceso reglamentario desprovisto de suficiente amparo legal, por contravenir el derecho europeo o, en fin, simplemente -y esta es la causa más habitual- por adolecer de defectos de procedimiento (en una gran mayoría de casos, vinculados a la omisión de informes y memorias preceptivos exigidos para su aprobación).

Pues bien, dejando aparte el complejo y tortuoso sistema de acceso para impugnar una norma presuntamente inválida, sea por inconstitucionalidad, infracción del derecho europeo o ilegalidad -sistema de recursos diseñado por el legislador ordinario que en ocasiones pudiera reputarse contrario al derecho a la tutela judicial efectiva (9)-, procede señalar como premisa general que nuestro ordenamiento carece de una regla común para fijar los efectos derivados de las sentencias anulatorias de normas, sean tributarias o no. En su lugar, como se apuntaba en la introducción, existen preceptos dispersos que refieren mínimamente los efectos derivados de la sentencia que invalida una norma y lo hacen, como regla general, refiriendo dichos efectos a la propia norma pero no siempre a los actos afectados por ella (art. 40 LOTC, art. 73 LJCA, art. 106.4 LPAC, art. 19.2 TRLRHL).

puesto en el número de cuestiones prejudiciales presentadas por juzgados y tribunales españoles. En particular, entre los años 2015 y 2019, se han elevado 591 cuestiones prejudiciales, de las cuales en el año 2019 se han planteado 64. Vid. https://curia.europa.eu/jcms/upload/docs/application/ pdf/2020-07/20201762_qdap20001esn_pdf.pdf [consultado el 8/10/2020].

En cambio, ante el TC, en el año 2019 se presentaron 33 cuestiones de inconstitucionalidad y 27 recursos de inconstitucionalidad. Vid., http://www.tribunalconstitucional.es/es/memorias/ Documents/MEMORIA-2019.pdf [consultado el 8/10/2020].

(9) Al respecto procede señalar que la STS de 21 de mayo de 2018 (rec. 113/2017, ECLI:ES:TS:2018:2054) ha calificado de "peaje" al sistema de recursos administrativos preceptivos que ineluctablemente deben pagar los administrados antes de poder impetrar la tutela judicial que consagra el artículo 24.1 CE. Por ello, el TS considera que la formulación de un recurso de reposición que tuviera como único fundamento la inconstitucionalidad de la norma legal que da cobertura al acto impugnado, en tanto que nunca podría resolverse por esta vía y no existe un instrumento procedimental que permita al órgano que debe resolverlo plantear la cuestión ante el Tribunal Constitucional, «resulta manifiestamente inútil e ineficaz para obtener el resultado querido», desproporcionado y vulnerador del derecho a obtener la tutela judicial efectiva y, en consecuencia, «no resulta obligatorio interponer, como presupuesto de procedibilidad del ulterior recurso contencioso administrativo, el correspondiente recurso administrativo previsto como preceptivo». En el Auto de admisión que dio origen a este fallo (ATS 7989/2017, de 6 de julio) también se inquiría sobre los supuestos de ilegalidad de normas reglamentarias, a los efectos de determinar si procedía o no mantener la preceptividad del recurso de reposición o de la vía económico administrativa, pero en el fallo el TS no da respuesta a esta pregunta. Actualmente, el TS tiene admitida en casación la cuestión de si es necesario agotar la vía económico administrativa cuando se plantea una infracción del derecho de la Unión Europea dado que estos los TEA no pueden plantear cuestiones prejudiciales y están obligados a inaplicar las normas nacionales contrarias al derecho europeo (ATS 10367/2020 de 5 de noviembre). 
Ante esta evidencia ¿deberían producir los mismos efectos las declaraciones de invalidez de una norma, sea por inconstitucionalidad, por infracción del derecho europeo o por ilegalidad? A mi juicio, respecto de estos "actos sin soporte legal" -como los ha denominado la doctrina alemana-, nuestro ordenamiento opta como regla general por la seguridad jurídica y la estabilidad de los actos firmes, esto es, por disociar la invalidez de la norma de la de los actos firmes afectados por ella. Es cierto que, en el caso de pronunciamientos de inconstitucionalidad, el artículo 40 LOTC no lo contempla así expresamente porque únicamente se refiere a la nulidad de la norma, pero así lo ha mantenido de forma reiterada el TC desde su STC 45/1989, de 20 de febrero, salvo escasas excepciones; también lo prevé así el artículo 73 LJCA respecto de las resoluciones judiciales que anulan una disposición general ("que no afectarán a los actos administrativos firmes que la hayan aplicado antes de que la anulación alcanzara efectos generales») y el artículo 106.4 LPAC con relación a la anulación de disposiciones que, sin perjuicio de admitir posibles indemnizaciones, proclama con rotundidad la subsistencia de los actos firmes dictados en aplicación de aquellas, al igual que hace el artículo 19.2 del TRLRHL. La regla general en favor de la intangibilidad de los actos firmes dictados al amparo de una norma inválida se confirma igualmente desde el momento en que esta situación no se contempla como causa de nulidad radical de los actos (art. 217 LGT), lo que no impide que esta pueda apreciarse si en ellos, intrínsecamente, concurre una causa tipificada legalmente de invalidez absoluta. La pretensión de remover sine die hacia atrás actos firmes afectados por la invalidez de una norma, como dogma iuris et de iure o como simple regla general, violenta además la seguridad jurídica y la estabilidad del sistema de relaciones entre la Administración y los administrados que son los parámetros que justifican -aunque pueda ser discutible- la presunción de validez y los privilegios de autotutela administrativa, ejecutoriedad y ejecutividad del acto administrativo. De hecho no cabe ignorar que, precisamente en aras de salvaguardar el interés general o la seguridad jurídica, existen fallos anulatorios que han preservado la intangibilidad de los actos no firmes (10) y pronunciamientos de inconstitucionalidad que no han traído consigo la nulidad de la norma permitiendo incluso su vigencia hasta la aprobación de la norma válida a modo de "nulidad diferida" (11). En todo caso, creo que es

(10) Así, entre otras, la STC 111/2016, de 9 de junio, relativa a la inconstitucionalidad de la D.A. $16^{a}$ de la Ley de racionalización y sostenibilidad de la Administración Local que permitía, con ciertos requisitos, la aprobación del presupuesto municipal por la Junta de Gobierno Local y no por el Pleno. Tras declarar la inconstitucionalidad de dicha disposición y la previsión del artículo 40 de la LOTC, el Tribunal señala que «Correspondiendo a este Tribunal precisar los efectos de la nulidad (STC 45/1989, de 20 de febrero), razones de seguridad jurídica (art. 9.3 CE) imponen en este caso acotar todavía más esos efectos: la declaración de inconstitucionalidad y nulidad de la disposición controvertida habrá de producir efectos ex nunc, a partir de la publicación de la presente Sentencia, sin que, por tanto, resulten afectados por ésta los presupuestos, planes y solicitudes ya aprobados por juntas de gobierno locales ni los actos sucesivos adoptados en aplicación de los anteriores, hayan o no devenido firmes en la vía administrativa».

(11) Vid., entre otras, STC 164/2013, de 26 de septiembre, que declaró la inconstitucionalidad y nulidad de ciertos preceptos legales referidos al régimen especial canario por haberse aprobado sin respetar el trámite de audiencia previa a la Comunidad Autónoma previsto en su Estatuto de Autonomía, declaración de inconstitucionalidad que el TC expresamente "difirió" y pospuso por el plazo de un año, periodo en el que las disposiciones declaradas nulas debían ser sustituidas por otras en las que se observara la garantía procedimental omitida. 
relevante señalar que esta regla general latente en nuestro ordenamiento y que protege la firmeza de los actos dictados al amparo de una norma inválida no empece, en mi opinión, para que los órganos jurisdiccionales, que pueden, modulen el alcance y los efectos de sus fallos atendida la causa de invalidez (formal o material), su propia gravedad, el número de personas afectadas, las repercusiones financieras o de otra índole, o la propia equidad de su pronunciamiento en función de las distintas situaciones afectadas.

En efecto, una segunda premisa general es que los órganos jurisdiccionales, al enjuiciar la validez de normas tributarias, pueden delimitar el alcance o los efectos de sus fallos. Ciertamente se trata de una competencia ampliamente reconocida y practicada en ocasiones (caso del TJUE), pero poco generalizada, indeterminada y desigual en otros (TC y órganos jurisdiccionales contencioso-administrativos). Por otro lado, conviene precisar que los pronunciamientos de invalidez de normas tienen un doble carácter: de una parte, declaran la nulidad de la norma, esto es, constatan una realidad jurídica anterior al pronunciamiento consistente en una antijuridicidad ya existente y, de otra, son constitutivos de los efectos que produce esa misma declaración de invalidez respecto de los actos dictados a su amparo pudiendo anularlos con o sin efecto retroactivo, en algunos casos, o incluso posponiendo los efectos con carácter diferido a un momento posterior. Ciertamente podría hablarse de una invalidez sobrevenida de los actos en estos casos, pero, a falta de un pronunciamiento expreso en la sentencia anulatoria, esa supuesta invalidez necesita de un acto administrativo o judicial expreso que la declare, lo que solamente puede hacerse a través de los sistemas de recursos o revisión -"instrumentos de reacción”- que prevé el ordenamiento sin que sea posible apreciar, automáticamente, una invalidez originaria, tácita y retroactiva del acto a partir de la sentencia que declara la invalidez de la norma que lo ampara (12).

Una tercera consideración general guarda relación con la cuestión de si, admitida la presunción de constitucionalidad, legalidad y hasta europeidad de la norma, ¿pueden los órganos jurisdiccionales y la Administración inaplicarla si la consideran inválida aunque no se haya declarado formalmente su invalidez? Esta inaplicación cabe en el supuesto de pronunciamientos interpretativos de invalidez que no llegan a anular la norma pero proclaman cómo deben interpretarse y aplicarse [como ha sucedido con la interpretación jurisdiccional de la exención en el IRPF de las prestaciones de maternidad (13)]. También en el caso de

(12) Sobre la invalidez sobrevenida vid., por todos, Cano Campos (2014).

(13) En efecto, a raíz de la interpretación primero del TSJ de Madrid (STSJ de Madrid de 6 de julio de 2016) y después del TS (STS de 3 de octubre de 2018, rec. 1462/2018), conforme a las cuales las prestaciones públicas de maternidad percibidas de la Seguridad Social están exentas del IRPF se planteó el problema de resolver las "miles" de reclamaciones (en su mayoría rectificación de autoliquidaciones) pendientes. Descartada la extensión de efectos como solución inicial (controvertida en tanto que solamente había una sentencia del TS -ATS 4088/2019- y se planteaba la duda de si el contribuyente debía haber instado o no la rectificación de su autoliquidación -ATS 3851/2019. y STS de 22 de enero de 2020, rec. 7961/2018, ECLI:ES:TS:2020:225), así como una utilización masiva de la revocación al amparo del art. 219 LGT -que la AEAT quería evitar "a toda costa" por el riesgo de su generalización para otros supuestos-, la Administración optó por una fórmula de "ingeniería jurídica" aprobando un Real Decreto-ley (RDL 27/2018, de 28 de diciembre) que articuló una especie de "revocación normativa" a partir de una simple solicitud para reclamar la devolución de las prestaciones de maternidad tanto en el caso de autoliquidaciones vivas, como desestimadas, 
normas reglamentarias y/o normas que infringen el derecho europeo es defendible el deber de inaplicarlas si su validez arroja dudas porque en estos casos prevalece, o bien el principio de jerarquía normativa dando preferencia a la aplicación de una norma o principio de superior rango -sea una Ley, la propia Constitución, una norma europea o un principio general de derecho- o bien la supremacía y efecto directo del derecho europeo cuando se dan ciertos requisitos. Así se infiere de lo previsto en el artículo 6 de la LOPJ conforme al cual «los Jueces y Tribunales no aplicarán Reglamentos o cualquier otra disposición contrarios a la Constitución, a la Ley o al principio de jerarquía normativa». Esto es, mientras que no es posible inaplicar una ley presuntamente inconstitucional hasta que no se haya declarado la inconstitucionalidad o suspendida su inejecución por dicho motivo, en el caso de infracciones de derecho europeo y en el de invalidez de normas reglamentarias, tanto la Administración como los órganos jurisdiccionales pueden y deben inaplicar la norma controvertida. Así lo ha reconocido expresamente el TS, asumiendo la postura del Consejo de Estado, señalando que «el deber de inaplicar las normas ilegales atañe no sólo a los Tribunales sino a las Administraciones Públicas: en efecto, aunque la Ley Orgánica del Poder Judicial impone a los Tribunales el deber de inaplicar los reglamentos ilegales (art. 6) y falte una norma equivalente referida a la Administración (...) el mantenimiento ilegal atentaría contra la seguridad jurídica y a la igualdad, principios constitucionalmente protegidos». Ciertamente, si la Administración aplica una norma reglamentaria contraria a la Ley, a la Constitución, al derecho europeo o a otra norma reglamentaria de superior jerarquía estaría vulnerando el principio de legalidad y de jerarquía normativa, establecidos en el artículo 9 de nuestra Constitución (14) o la primacía y efecto directo del derecho europeo. Por ello, o bien la inaplica o bien la anula si es competente para ello o bien insta la cuestión de ilegalidad (ATS 10454/2020, de 13 de noviembre de 2020, ECLI:ES:TS:2020:10454A).

Una última premisa general sobre la invalidez de las normas tributarias. En nuestro ordenamiento, salvo escasas excepciones, las causas de invalidez de la norma no están condicionando sus efectos. Sin embargo, creo que dentro del margen de decisión de los órganos jurisdiccionales para modular el alcance de sus fallos, debiera avanzarse en esta línea hacia una práctica que tuviera en cuenta, en particular, la entidad y naturaleza de la tacha de invalidez. Es decir, la causa de invalidez de la norma debe repercutir en los efectos derivados de su anulación. No es lo mismo, no tiene el mismo alcance material, declarar la inconstitucionalidad de una Ley por infracción del principio de reserva de Ley, por una cuestión esencialmente formal (por ejemplo, por haberse incluido una modificación tributaria en una Ley de Presupuestos o haberse regulado mediante Decreto-ley), que hacerlo porque la norma tributaria ha contravenido el reparto competencial, ha provocado doble imposición o adolece de una razón sustantiva o de fondo, vinculada con el principio de igualdad, capacidad económica o progresividad o referida a un derecho fundamental (como ha sucedido con la inconstitucionalidad de ciertas tasas judiciales en tanto que violentaban el derecho a la tutela judicial efectiva). Por el mismo motivo no deben tener, y de hecho no lo tienen, los efectos

e incluso en el caso de que hubieran sido objeto de liquidaciones firmes por otros motivos.

(14) Vid. STS de 2 de julio de 2020, rec. 51/2018, ECLI:ES:TS:2020:2059. Al respecto vid., por todos, Domenech Pascual (2002). En la misma línea, a juicio de Martín Queralt (2019), también los órganos económico-administrativos están obligados a inaplicar normas reglamentarias ilegales, aunque no se haya declarado formalmente su ilegalidad, no siendo admisible declarar la inadmisión de la reclamación cuando se invoca la ilegalidad de la norma reglamentaria. 
derivados de las declaraciones del TJUE cuando declara la infracción del derecho europeo por razones formales (retraso en la transposición de una Directiva, por ejemplo) o materiales por tratarse de una «violación suficientemente caracterizada» que atenta claramente contra el acervo europeo. Y, en fin, tampoco deberían producir los mismos efectos la declaración de ilegalidad de una norma reglamentaria porque concurran razones formales (por ejemplo, por la ausencia de la memoria económico financiera en la ordenanza que regula una tasa o la ausencia de alguno de los "miles" de informes que se exigen para la aprobación de planes urbanísticos) o materiales (por ejemplo, porque la norma reglamentaria ha ampliado el ámbito de sujeción tributaria al regular los elementos de una obligación tributaria o ha recortado la configuración legal de una exención tributaria).

\section{EFECTOS DERIVADOS DE LAS SENTENCIAS ANULATORIAS DE NORMAS TRIBUTARIAS}

\subsection{Efectos derivados de pronunciamientos de inconstitucionalidad}

En el caso de vicios de inconstitucionalidad, dejando al margen los supuestos de declaraciones interpretativas de inconstitucionalidad [como ha sucedido con las sentencias relativas al IIVTNU (15)], el artículo 39.1 LOTC establece que «Cuando la sentencia declare la inconstitucionalidad, declarará igualmente la nulidad de los preceptos impugnados, así como, en su caso, la de aquellos otros de la misma Ley, disposición o acto con fuerza de Ley a los que deba extenderse por conexión o consecuencia». La declaración de inconstitucionalidad implica, de suyo y por tanto, la "nulidad" de los preceptos impugnados y de aquellos otros de la misma norma a los que deba extenderse por conexión o consecuencia. Estos pronunciamientos de inconstitucionalidad «tendrán el valor de cosa juzgada, vincularán a todos los Poderes Públicos y producirán efectos generales desde la fecha de su publicación en el Boletín Oficial del Estado» (art. 38.1). Ahora bien, «Las sentencias declaratorias de la inconstitucionalidad de Leyes, disposiciones o actos con fuerza de Ley no permitirán revisar procesos fenecidos mediante sentencia con fuerza de cosa juzgada en los que se haya hecho aplicación de las Leyes, disposiciones o actos inconstitucionales, salvo en el caso de los procesos penales o contencioso-administrativos referentes a un procedimiento sancionador en que, como consecuencia de la nulidad de la norma aplicada, resulte una reducción de la pena o de la sanción o una exclusión, exención o limitación de la responsabilidad» (art. 40.1 LOTC).

A riesgo de simplificar el contenido de este marco normativo, tres consideraciones resultan relevantes: en primer lugar, que -a priori- la declaración de inconstitucionali-

(15) En mi opinión esta sentencia contiene un pronunciamiento interpretativo al proclamar una inconstitucionalidad relativa o parcial ("el IIVTNU no es, con carácter general, contrario al Texto constitucional, en su configuración actual» dice el TC respecto de los arts. 107.1 y 107.2 TRLRHL) y, en cierta medida, una "inconstitucionalidad por omisión" en la medida en que los preceptos impugnados no contenían ninguna regla que permitiera discernir en que supuestos no se realiza el hecho imponible cuando no se produce un incremento de valor. Debe advertirse, por otra parte, que la proliferación de sentencias anulatorias interpretativas, no sólo por parte del TC sino también de otros órganos jurisdiccionales (en particular del TJUE), cuando se convierte en una práctica generalizada, perjudica la seguridad jurídica y genera una amplia disparidad judicial en su aplicación. 
dad implica la nulidad de la norma (o del precepto impugnado); en segundo lugar, que la declaración de inconstitucionalidad tiene eficacia erga omnes y vincula a todos los poderes públicos desde su publicación, lo que significa que afecta a las situaciones "vivas" al momento de publicarse el fallo, esto es, vinculan tanto a la Administración al aplicar las normas tributarias como a los órganos jurisdiccionales al tiempo de enjuiciarlas no pudiendo desconocer el pronunciamiento de invalidez de la norma, habilitándose así la rectificación de las autoliquidaciones cuya no revisión no estuviera prescrita y la impugnación de las liquidaciones que aún no fueran firmes (16) y en tercer lugar, que la declaración de inconstitucionalidad impide revisar los procesos concluidos mediante sentencia firme, salvo los referentes a un procedimiento sancionador cuando resulte una aplicación más favorable.

Ahora bien, la regulación contenida en la LOTC no aclara si la nulidad de la norma asociada a la declaración de inconstitucionalidad es retroactiva, ex tunc, o ex nunc; tampoco resuelve cómo afecta esa nulidad a los actos firmes dictados al amparo de la norma inconstitucional ni prevé, en el caso particular de pronunciamientos de inconstitucionalidad, si el TC puede modular o no de algún modo los efectos de sus fallos o si la causa de invalidez condiciona de algún modo los efectos de la sentencia.

En efecto, el principal problema que plantean las sentencias de inconstitucionalidad es si afectan o no a los actos firmes o, en términos del TC, a las "situaciones consolidadas" dictados al amparo de la norma inconstitucional, esto es, si cabe la posibilidad de otorgar efectos retroactivos a las declaraciones de inconstitucionalidad ya que, literalmente, el artículo 40.1 LOTC solo impide la retroactividad respecto de «los procesos fenecidos mediante sentencia con fuerza de cosa juzgada en los que se haya hecho aplicación de las Leyes, disposiciones o actos inconstitucionales» (17). Como es sabido, el TC, autointerpretando su propia normativa orgánica, ha considerado -ya desde el clásico fallo contenido en la STC 45/1989, de 20 de febrero- que «la LOTC deja a este Tribunal la tarea de precisar su alcance (el de la declaración de nulidad) en cada caso» en atención, fundamentalmente, al principio de seguridad

(16) El problema que se plantea, en muchas ocasiones, es qué norma aplicar en sustitución de la declarada inconstitucional. En el caso de la plusvalía, algunos órganos jurisdiccionales optaron por una posición maximalista, esto es, considerar que no habiendo sustituido el legislador la norma inconstitucional, se carecía de parámetro legal y supondría un "arbitrio del aplicador tanto la determinación de los supuestos en los que nacería la obligación tributaria como la elección del modo de llevar a cabo la determinación del eventual incremento o decremento», lo que en definitiva y a la postre supondría una quiebra de la seguridad jurídica y de la reserva de ley en materia tributaria (por todas, STJ Madrid de 19 de julio de 2017, rec. 783/2016, ECLI: ES:TSJM:2017:7443 y STSJ Navarra de 6 de febrero de 2018, rec. 535/2016, ECLI:ES:TSJNA:2018:1). Otros en cambio, en atención a las pruebas aportadas bien por la Administración bien por el contribuyente a los efectos de acreditar la existencia o inexistencia de incremento resolvieron sobre la nulidad o validez de la liquidación girada (vid., por todas, la STJS de Valencia de 6 de julio de 2017, rec. 3/2017, ECLI: ES:TSJCV:2017:4675). La STS de 9 de julio de 2018 (rec. 6226/2017, ECLI: ES:TS:2018:2499) ha tildado de "desatinada" la referida tesis maximalista. Entre la abundante bibliografía sobre esta controversia vid., por todos, Marín-Barnuevo Fabo (2017), Pagés i Galtés (2019) y Ruiz Almendral (2018).

(17) Vid., por todos, Jiménez Campo (1997). 
jurídica (art. 9.3 CE) y, en menor medida, al principio de igualdad (art. $14 \mathrm{CE}$ ) (18). Respecto de otros procesos constitucionales, el TC sí dispone de habilitación legal expresa para modular el alcance de sus fallos. Así, en el artículo 55.a) LOTC se prevé, en el caso de sentencias que resuelven recursos de amparo, la posibilidad de que declaren la «nulidad de la decisión, acto o resolución que hayan impedido el pleno ejercicio de los derechos o libertades protegidos, con determinación, en su caso, de la extensión de sus efectos» (19). Asimismo, el art. 66 de la LOTC también contempla expresamente la competencia del TC para modular los efectos de las sentencias que resuelvan conflictos de competencia al disponer que «La sentencia declarará la titularidad de la competencia controvertida y acordará, en su caso, la anulación de la disposición, resolución o actos que originaron el conflicto en cuanto estuvieren viciados de incompetencia, pudiendo disponer lo que fuera procedente respecto de las situaciones de hecho o de derecho creadas al amparo de la misma». Sin embargo, ese reconocimiento legal expreso para modular el alcance de sus fallos no está contemplado en el caso de pronunciamientos de inconstitucionalidad (20). Sorpresivamente, dicha habilitación ha venido reconocida indirectamente, no en su Ley orgánica reguladora -donde debiera-, sino en el artículo 32.6 de la LRJSP cuando, con ocasión de la regulación de la responsabilidad patrimonial del Estado legislador, dispone que «La sentencia que declare la inconstitucionalidad de la norma con rango de ley o declare el carácter de norma contraria al Derecho de la Unión Europea producirá efectos desde la fecha de su publicación en el "Boletín Oficial del Estado" o en el "Diario Oficial de la Unión Europea", según el caso, salvo que en ella se establezca otra cosa», así como en el artículo 34.1 de la misma norma al establecer «En los casos

(18) El principio de igualdad como límite a la revisión de las situaciones administrativas firmes se invoca porque la conclusión contraria «entrañaría un inaceptable trato de disfavor para quien recurrió, sin éxito, ante los Tribunales en contraste con el trato recibido por quien no instó en tiempo la revisión del acto de aplicación de las disposiciones hoy declaradas inconstitucionales» (entre otras, SSTC 45/1989, de 20 de febrero, FJ 11 y 180/2000, de 29 de junio, FJ 7).

(19) El TC ha señalado la compatibilidad de los efectos derivados de procesos de amparo a todos los que se encontraran en esa situación, con la limitación de efectos que establece el artículo 40.1 LOTC que a priori, deja intangibles a los actos confirmados por sentencia con fuerza de cosa juzgada. Así, a título de ejemplo, tras la declaración de inconstitucionalidad de ciertas tasas judiciales (entre otras, SSTC 140/2016 y 55/2017), al tiempo de resolver los efectos derivados de un recurso de amparo suscitado por el mismo motivo, el TC señaló que «... debe entenderse que, de acuerdo con el artículo 55.2 LOTC, este Tribunal está obligado a extender los efectos de la declaración de inconstitucionalidad y nulidad de una ley, no solo al concreto recurso de amparo que hubiera motivado la elevación de la cuestión interna de inconstitucionalidad (SSTC 5/2011, de 14 de febrero y 63/2016, de 11 de abril), sino también a los demás recursos de amparo interpuestos con anterioridad a esa declaración y que se fundamentan en la misma inconstitucionalidad de la Ley (SSTC 75/2016, 76/2016 y 77/2016), sin que para ello constituya obstáculo o impedimento alguno la noción de "procesos fenecidos mediante sentencia con fuerza de cosa juzgada" establecida en el artículo 40.1 LOTC» (STC 70/2017, de 5 de junio).

(20) Y es expresamente negado y cuestionado por algún autor para quien «resultaría incompatible con la división constitucional de poderes y con su condición de intérprete constitucional que el Tribunal Constitucional "decidiera" sobre los efectos de sus declaraciones de inconstitucionalidad. Ni la Constitución ni la LOTC le "dejan" al TC la determinación de los efectos de su fallo estimatorio», vid., Ruiz Zapatero (2006). 
de responsabilidad patrimonial a los que se refiere los apartados 4 y 5 del artículo 32 , serán indemnizables los daños producidos en el plazo de los cinco años anteriores a la fecha de la publicación de la sentencia que declare la inconstitucionalidad de la norma con rango de ley o el carácter de norma contraria al Derecho de la Unión Europea, salvo que la sentencia disponga otra cosa». Es obvio que estos preceptos no mencionan, ni podrían hacerlo, qué tipo de efectos pueden establecerse en una sentencia que declare la inconstitucionalidad de una norma, pero sí establecen con carácter general que los efectos de una sentencia de inconstitucionalidad se producirán «desde su publicación en el BOE» "salvo que en ellos se establezca otra cosa". Tal inciso, criticable desde luego por interferir desde una ley ordinaria en la regulación orgánica de los efectos de las sentencias de inconstitucionalidad, si bien no impide la retroactividad de las sentencias de inconstitucionalidad, parte de la premisa generalizada de su prospectividad desde su publicación (21).

Pues bien, en este contexto, como es sabido, en aras de salvaguardar el principio de seguridad jurídica (art. 9.3 CE), así como del principio de igualdad (art. 14) y la protección de los intereses financieros en muchos casos -razonamiento implícito que no explícito-, las sentencias de inconstitucionalidad en materia tributaria tienen como regla general eficacia prospectiva, esto es, afectan a los actos "vivos" pero dejan incólumes las "situaciones consolidadas" (actos firmes) afectados por la declaración de inconstitucionalidad (22). Esta es la práctica habitualmente seguida por el TC y recogida expresamente en sus fallos con alguna excepción, como ha sido la STC 59/2017, de 11 de mayo, referida a la IIVTNU, en la que el TC omitió precisar el alcance de su declaración de inconstitucionalidad lo que ha generado una amplísima controversia jurisprudencial al tiempo de interpretar qué significaba ese silencio del TC (23). Personalmente he de reconocer que esa omisión -a mi juicio, seguramente un olvido- en ningún caso permitía entender que el TC era partidario de una eficacia retroactiva de su pronunciamiento de inconstitucionalidad. Así lo ha confirmado el fallo explícito de la posterior STC 126/2019, de 31 de octubre sobre el mismo gravamen (24). Esa interpretación ni casaba con la práctica reiterada

(21) También crítica con la regla general de prospectividad de las sentencias de inconstitucionalidad que se deduce de este art. 32.6 LRJSP se ha manifestado Triana Reyes (2017).

(22) Al respecto son clásicos los trabajos de Rubio Llorente (1988) y de Jiménez Campo (1997). A mi juicio, en la expresión "situaciones consolidadas" habitualmente reiterada por el TC en sus fallos prospectivos se está haciendo referencia a actos cuya revisión no sea posible por los mecanismos ordinarios de impugnación, esto es, con carácter general, actos firmes. Quedarían al margen, en cambio, aquellos actos cuya rectificación o revisión fuera posible sin acudir a un sistema extraordinario. Y a estos efectos, entiendo que la rectificación de las autoliquidaciones no encaja materialmente en esta categoría. Vid., infra, nota 50.

(23) Vid., supra nota 16.

(24) En efecto, en la STC 126/2019, de 31 de octubre, que declaró la inconstitucionalidad del artículo 107.4 TRLRHL cuando la aplicación de la regla de cálculo que contiene determina un incremento de valor superior al efectivamente obtenido por el sujeto pasivo, el TC sí concreta el alcance de su fallo estableciendo que «Por exigencia del principio de seguridad jurídica (art. 9.3 CE), y al igual que hemos hecho en otras ocasiones (por todas, SSTC 22/2015 de 16 de febrero, FJ 5, y 73/2017, de 8 de junio, FJ 6), únicamente han de considerarse situaciones susceptibles de ser revisadas con fundamento en esta sentencia aquellas que, a la fecha de publicación de la misma, no 
y constante de sus pronunciamientos prospectivos en materia tributaria (25), ni era la seguida por el Consejo de Estado al dictaminar revisiones de oficio amparadas en la inconstitucionalidad de la norma (26), ni se había admitido por el TS en muchos otros supuestos precedentes de la última década -salvo en algún caso notorio, ciertamente, como la STS del Pleno de 2 de junio de 2010, rec. 588/2008, ECLI:ES:TS:2010:3898 que contó con numerosos votos particulares- en los que tampoco la sentencia de inconstitucionalidad se pronunciaba sobre el alcance de sus efectos (27). Desde luego, vista la controversia suscitada por la interpretación del fallo de la STC 59/2017, dudo que en el futuro el TC omita pronunciarse sobre el alcance de sus fallos. Y en todo caso, lo que importa destacar es que, en aquellos supuestos en los que el TC, pudiendo hacerlo, no ha establecido el alcance temporal de su declaración de inconstitucionalidad -asuminiendo el riesgo de interpretar el fallo en un sentido contrario al querido por el TC-, el propio TS ha señalado que "corresponde a este Tribunal Supremo -en aplicación de la legalidad ordinaria- determinar en qué medida esa declaración puede tener efectos para el contribuyente a quien le fueron giradas liquidaciones aplicando los preceptos considerados parcialmente inconstitucionales cuando tales liquidaciones ganaron firmeza por no haber sido recurridas en tiempo y forma» (28). Desde el año 2010 ésta ha sido la posición mayoritariamente sostenida por el TS: si las sentencias de inconstitucionalidad no dicen otra cosa, no tienen efectos retroactivos.

hayan adquirido firmeza por haber sido impugnadas en tiempo y forma, y no haber recaído todavía en ellas una resolución administrativa o judicial firme».

(25) Baste citar, entre las más recientes y reiterando la clásica doctrina de la STC 45/1989, las SSTC 180/2000, de 29 de junio, 54/2002, de 27 de febrero, 60/2015, de 18 de marzo, 73/2017, de 8 de junio, 92/2017, de 6 de julio, 126/2019, de 31 de octubre, y 78/2020 de 1 de julio.

(26) Sorprende, sin embargo, la reciente postura mantenida por el Consejo de Estado en su Dictamen 197/2019 (y en otros similares) con relación a los efectos derivados de la inconstitucionalidad del Decreto-ley 13/2014, de 3 de octubre, por el que se adoptaron diversas medidas urgentes en relación con el sistema gasista y, en particular, por el que se articuló el pago de diversas liquidaciones de las empresas afectadas por la hibernación de la instalación de almacenamiento subterráneo de gas natural "Castor". Tras la declaración de inconstitucionalidad del citado Real Decreto-ley (por falta de extraordinaria y urgente necesidad) la CNMV instó la revisión de oficio de las liquidaciones satisfechas a las empresas afectadas. Pues bien, en el Dictamen que examina esa revisión de oficio, como puso de manifiesto el voto particular que se formuló al mismo, resulta sorprendente que el Consejo de Estado entendiera que cuando el TC no concretase el alcance temporal de sus pronunciamientos de inconstitucionalidad, había que entender que la declaración de inconstitucionalidad tenía eficacia erga omnes y ex tunc, en vez de seguir la reiterada doctrina consultiva favorable a los efectos prospectivos de los fallos de inconstitucionalidad. Como se afirma en el citado voto particular, haciendo hincapié en el cambio de registro, «no es posible, sin incurrir en grave contradicción, sugerir que la declaración de inconstitucionalidad de una ley determina por sí misma la nulidad de los actos administrativos firmes y, al mismo tiempo, afirmar que la nulidad de tales actos proviene de la causa de nulidad del artículo 47.1.f) de la Ley 39/2015».

(27) Vid., entre otras, las SSTS de 8 de junio de 2017 (rec. 2739/2015, ECLI: ES:TS:2017:2424 y rec. 2741/2015, ECLI:ES:TS:2017:2280).

(28) Vid., SSTS de 18 de mayo de 2020, rec. 1665/2019 (ECLI:ES:TS:2020:973), rec. 2596/2019 (ECLI:ES:TS:2020:970) y rec. 1068/2019 (ECLI:ES:TS:2020:984). 
Una segunda observación que se deduce de la jurisprudencia constitucional tributaria es que los efectos de la invalidez de la norma, hasta la fecha, no se han modulado en atención a la causa de invalidez de la misma o a la mayor o menor infracción palmaria del texto constitucional. Esto es, tanto si la inconstitucionalidad de la norma tributaria ha sido por infracción del principio de reserva de Ley tributaria (ya fuera por modificaciones tributarias introducidas en Leyes de Presupuestos, en Decretos-leyes o por infracción misma de la reserva de Ley en los términos que ha interpretado el TC el artículo $31 \mathrm{CE}$ ), por falta de competencia material (supuestos de gravámenes autonómicos que infringen el principio de prohibición de doble imposición) o, incluso, por infracciones del principio de igualdad o del de capacidad económica, o incluso por infracciones de otros derechos constitucionales (inconstitucionalidad de las tasas judiciales por contravenir el derecho a la tutela judicial efectiva), el alcance de la jurisprudencia constitucional ha sido igualmente prospectivo. Sin embargo, a mi juicio, sería oportuno y deseable que el TC avanzara en esta línea y modulara los efectos de sus declaraciones de inconstitucionalidad en función de la causa de invalidez de la norma, de la entidad de la infracción constitucional cometida o, incluso, de la búsqueda de efectos equivalentes de sus fallos como podría haber sido, por ejemplo, establecer que la inconstitucionalidad del IIVTNU afectara tanto a autoliquidaciones no prescritas como a liquidaciones ya firmes que se hubieran dictado en un plazo equivalente (cuatro años) (29). Al igual que la jurisprudencia europea solo aprecia la responsabilidad de los estados miembros por infracción del derecho europeo cuando estamos ante "violaciones suficientemente caracterizadas", o en el ámbito de la anulación de los actos administrativos y disposiciones generales la posible responsabilidad de la Administración se pondera -no sin cuestionarla- en función de la tesis del "margen de tolerancia" de modo que no ha lugar a la responsabilidad si la actuación de la Administración fue razonable y razonada, sería conveniente tomar en consideración la causa de inconstitucionalidad (formal o material), y cualesquiera otras circunstancias relevantes para delimitar los efectos temporales y materiales de las sentencias de inconstitucionalidad. En mi opinión, no debería tener el mismo alcance la inconstitucionalidad de una norma por infracción del principio de reserva de Ley (por ejemplo, por haberse regulado en una Ley de Presupuestos o en un Decreto-Ley) que cuando, además, violenta de modo significativo alguno de los principios materiales del derecho tributario, principalmente, el de igualdad (si se trata de beneficios fiscales), el de capacidad económica o el de prohibición de doble imposición, u otros de relevancia constitucional (como el derecho a la tutela judicial efectiva, los derechos de defensa, la intimidad o la inviolabilidad del domicilio).

(29) Al respecto procede advertir que el ATC 116/2019, de 15 de octubre, ha inadmitido la cuestión de inconstitucionalidad elevada por el $\mathrm{JCA} \mathrm{n}^{\circ} 2$ de Alicante que invocaba la quiebra del principio de igualdad con relación al pago de la plusvalía afectada por la STC 59/2017 según se pagara mediante autoliquidación o liquidación administrativa. El TC inadmite la cuestión de un lado, por razones formales, porque en el trámite de audiencia solamente se invocó el principio de igualdad y, sin embargo, en el auto judicial que elevó la cuestión se alegó adicionalmente el principio de capacidad económica y, de otro, porque la existencia de distintos regímenes de gestión tributaria no implicaba una afectación del referido principio de igualdad. 


\subsection{Efectos derivados de declaraciones de ilegalidad de normas reglamentarias o disposiciones generales}

Resulta curioso que la declaración de inconstitucionalidad de una norma lleve asociada su "nulidad" -sin adjetivos- ex art. 39 LOTC y que, sin embargo, la declaración de invalidez de una norma reglamentaria esté sancionada por el legislador con la "nulidad de pleno derecho" (art. 47.2 LPAC). Seguramente en ello subyace cierta suspicacia del legislador hacia una práctica reglamentaria abusiva o ilegal. En todo caso, como interpretar más gravemente la ilegalidad de una norma reglamentaria que la inconstitucionalidad de una Ley sería un absurdo, hay que considerar que ambos regímenes coinciden y se limitan a señalar la invalidez de la norma, su nulidad, pero insisto, únicamente de la norma misma y no la de los actos afectados por ella.

Se observa también que, frente al ambiguo silencio de la LOTC para delimitar el alcance temporal de las sentencias de inconstitucionalidad, la ley jurisdiccional opta expresa y rotundamente por proclamar la prospectividad de las sentencias de que declaren la invalidez de una disposición general. Así lo dispone expresamente el artículo 73 de la LJCA cuando señala que «Las sentencias firmes que anulen un precepto de una disposición general no afectarán por sí mismas a la eficacia de las sentencias o actos administrativos firmes que lo hayan aplicado antes de que la anulación alcanzara efectos generales, salvo en el caso de que la anulación del precepto supusiera la exclusión o la reducción de las sanciones aún no ejecutadas completamente». La nulidad radical de la disposición general no implica, en consecuencia, la nulidad radical y retroactiva de los actos firmes afectados. Es más, como ha señalado la doctrina administrativa "la caracterización de los reglamentos ilegales como nulos de pleno derecho no tiene significado jurídico alguno más allá de la potestad exclusiva de la Administración de revisar de oficio el Reglamento» declarando simplemente su invalidez e inaplicablidad y, en su caso, establecer indemnizaciones conforme al artículo 106.4 LPAC (30). También lo ha reconocido así expresa y recientemente el TS al señalar, con ocasión de la revisión de oficio instada por una empresa frente a un Decreto que convalidaba la tasa por gastos y remuneraciones en dirección e inspección de obras -revisión de oficio desestimada porque, tratándose de una disposición general, solo la Administración tiene legitimación para instarla-, que la pretensión de la recurrente de atribuir efectos ex tunc a la anulación de una disposición general no tiene fundamento. Con sus palabras: «esta distinción en la producción de los efectos jurídicos entre la declaración de nulidad y la anulación, que tiene sus raíces en el derecho romano y en el derecho civil (donde tampoco rige absolutamente, basta una lectura de los efectos de la nulidad de los contratos prevista en los artículos 1300 a 1314) en el campo del derecho administrativo no tiene cobertura legal, aunque haya sido acogida por gran parte de la doctrina. Los efectos retroactivos de la declaración de nulidad y la mera anulación, vendrán determinados por lo que en cada momento disponga la Ley. Y de momento no existe ninguna norma que disponga que la

(30) Vid., Baño León (2019: 53). Entre la numerosa doctrina administrativa que ha abordado la invalidez de los reglamentos y sus efectos, en particular, son especialmente relevantes los trabajos de Santamaría Pastor (1975), Rebollo Puig (2018), Agoués Mendizábal (2017) y Teso Gamella (2019). 
declaración de nulidad suponga siempre la aplicación retroactiva de sus fallos» (STS de 2 de julio de 2020, rec. 51/2018, ECLI: ES:TS:2020:2059) (31).

Por otro lado conviene advertir que el TS ha abierto la posibilidad (en relación con los planes urbanísticos) de que la nulidad radical de los mismos cuando es debida a cuestiones de procedimiento (generalmente, omisión de informes preceptivos) se limite a una nulidad parcial dejando "viva" aquella parte del planeamiento no afectada por el vicio de invalidez, lo que implica, de facto, recortar el alcance temporal y material de las sentencias que declaran la ilegalidad de disposiciones reglamentarias (32). Esta línea jurisprudencial se alinea así con la doctrina administrativa que no solo cuestiona la dualidad nulidad/ anulabilidad, sino también los efectos asociados a cada una de estas categorías y la rigidez con la que se interpreta la nulidad radical debida a la omisión de defectos procedimentales en el ámbito de disposiciones reglamentarias (como sucede en el caso de planes urbanísticos) (33). La principal controversia es, por tanto, en el caso de disposiciones generales, determinar si la invalidez por motivos formales trae consigo la nulidad radical íntegra de toda ella o es admisible una invalidez parcial, en todo caso prospectiva.

Ciertamente, la revisión de estos viejos dogmas sobre la nulidad radical de disposiciones generales lo que postulan es que, del mismo modo que los vicios de los actos administrativos reciben distintas soluciones de invalidez en función de su gravedad, también los referidos a defectos que afectan a disposiciones reglamentarias debería calibrarse en función de la tacha (formal o material) de ilegalidad. De este modo, o bien la invalidez de las disposiciones generales debería examinarse en términos de "nulidad" o de simple "anulabilidad" en función de la naturaleza del vicio que le afecta, o bien debería proclamarse su eficacia prospectiva de modo similar a como operan los pronunciamientos de inconstitucionalidad atendidas las circunstancias y causas de invalidez. En todo caso, es claro que el artículo 73 LJCA no establece que los actos dictados al amparo de una norma reglamentaria ilegal sean válidos o nulos, simplemente determina que la declaración de nulidad de la disposición general no afectará a los que fueran firmes lo que, de facto, y procede destacarlo, en ningún caso impide la revisión de oficio de los mismos si en ellos concurrieran intrínsecamente causas de invalidez radical.

(31) A este respecto, como ha señalado muy certeramente Cano Campos, procede destacar que la doctrina administrativa se está cuestionando la dualidad de regímenes entre nulidad y anulabilidad y la dogmática tradicional aplicada a uno y otro régimen que, en muchos casos, carece de fundamento legal. Así sucede, por ejemplo, con la atribución de eficacia ex tunc o retroactiva a los pronunciamientos imperativos que declaran la nulidad frente a los efectos ex nunc de los que determinan la anulabilidad, dogma que califica de "mito". En este sentido, procedería replantearse una revisión crítica de la situación actual que atribuye distintos efectos a los supuestos de nulidad de pleno derecho y de anulabilidad, y también en relación con la convalidación, la revisión de oficio, la legitimación, la prescripción y la suspensión de modo que sea posible adaptar el régimen jurídico de la invalidez al interés protegido por la norma en cada caso pues no todos los supuestos de invalidez son equiparables, vid. Cano Campos (2017) y Martín Rebollo (2019).

(32) Vid., STS de 4 de marzo de 2020, rec. 2560/2017, ECLI:ES:TS:2020:744 y de 27 de mayo de 2020, rec. 6731/2018, ECLI:ES:TS:2020:1300.

(33) Al respecto vid., López Ramón (2018), González Sanfiel (2018) y Martín Rebollo (2019). 
Por otro lado, interesa observar que los efectos de la anulación judicial de una disposición general varían según la impugnación haya sido directa o indirecta. En el recurso indirecto donde, en aplicación del artículo 27.1 LJCA y según reiterada jurisprudencia, no se admite la invocación de defectos de procedimiento de la norma ilegal salvo que se trate de omisiones clamorosas, total y absolutas del procedimiento establecidas para su aprobación (34), la declaración de nulidad se limita al acto administrativo impugnado sin afectar a los demás actos dictados en aplicación de la norma que no hubieran sido impugnados, conservando además su plenitud jurisdiccional cualquier otro órgano que conozca de otros recursos indirectos sobre la misma norma. A este respecto interesa destacar, de una parte, que en el ámbito tributario el TS tiene admitida en casación la cuestión de «determinar si con ocasión de la impugnación indirecta de una ordenanza fiscal -la tasa de basuras, en el caso examinado- cabe alegar la omisión o la insuficiencia de los informes técnico económicos a que se refiere el artículo 25 del TRLHL, por entenderse que se trata del incumplimiento de un requisito sustantivo determinante de un elemento esencial del tributo, o si, por el contrario, no cabe tal invocación por constituir un mero vicio formal del procedimiento y, como tal, no susceptible de alegación en la impugnación indirecta de una disposición general». Y, de otra, que el TS ha rechazado la posibilidad de extender los efectos derivados de sentencias que han anulado liquidaciones del IBI por defectos formales de las ponencias de valores constatados en procesos referidos a otros contribuyentes cuando no existe un pronunciamiento del órgano competente para pronunciarse sobre la validez o invalidez de la referida ponencia, esto es, que sin la previa anulación formal de la disposición general u acto administrativo de alcance general (como se califican las ponencias de valores) no cabe extender los efectos de pronunciamientos que han resuelto recursos indirectos contra dicha disposición general (35).

(34) Vid., STS de 19 de abril de 2012, rec. 3252/2009. Al respecto vid., Baño León (2019: 60 y ss.).

(35) La controversia planteada puede resumirse así: el TSJ de Valencia al enjuiciar determinados recursos contra liquidaciones del IBI por defectos formales de la ponencia de valores (ausencia de estudio de mercado) estimó nulas las liquidaciones por dichos defectos. Con posterioridad, un contribuyente del mismo municipio impugnó su respectiva liquidación del IBI y el JCA, aplicando la extensión de efectos e invocando los principios de generalidad e igualdad, anuló también esta liquidación. Instada la casación de esta sentencia, el TS resuelve -acertadamente en mi opiniónque «a) Carece de eficacia de cosa juzgada material respecto de liquidaciones del Impuesto sobre Bienes Inmuebles posteriores (como las que constituye el acto enjuiciado en este proceso) la decisión anterior, adoptada por el tribunal competente para enjuiciar la gestión tributaria, por la que se anula una liquidación de dicho impuesto por defectos formales de la Ponencia de Valores. b) Tal decisión no impide al órgano judicial competente para enjuiciar esa misma Ponencia de Valores determine en el recurso dirigido frente a la misma -con plena cognición- si ésta es o no conforme a Derecho, incluida, lógicamente la concurrencia o no de aquellos defectos formales. c) No es posible anular la liquidación del IBI por defectos de la Ponencia de Valores -constatados en procesos referidos a otros contribuyentes- cuando, como sucede en el caso de que analizamos, la Sala de lo Contencioso-Administrativo de la Audiencia Nacional ha declarado ajustada a derecho dicha Ponencia en sentencia firme», vid., STS de 18 de mayo de 2020, rec. 5665/2018, ECLI:ES:TS:2020:971. Sobre esta problemática, que conecta con lo apuntado anteriormente acerca de la insuficiente regulación de la prejudicialidad y suspensión de procesos hasta que se despeje la validez de la norma, referido a disposiciones reglamentarias, vid., Huergo Lora (2012). 
Por contra, en el recurso directo, que adolece de una evidente restricción temporal, los efectos tienen alcance general, para todas las personas afectadas por dicha disposición aunque con las limitaciones del artículo 73 LJCA esto es, dejando incólumes los actos firmes. En esta línea, el TS ha señalado recientemente, con relación a la posibilidad de extender los efectos de la anulación de un Acuerdo de Consejo de Ministros de la asignación de derechos de emisión respecto de una concreta recurrente por razón de la nulidad de la norma reglamentaria que sirvió de soporte a dicha asignación, que «tal nulidad reglamentaria.... no implica que, aquí y ahora, por la vía de la revisión de oficio, también determine la nulidad de la asignación de la entidad aquí recurrente... en modo alguno puede afirmarse que la nulidad de la norma reglamentaria implique -siempre- la nulidad de las otras asignaciones no impugnadas (.) La eficacia expansiva de la nulidad de una norma reglamentaria ha de matizarse cuando se pretende extender la misma a los actos de aplicación dictados en el desarrollo de dicha norma reglamentaria ya que, en estos supuestos, en virtud del artículo 73 de la LJCA, la declaración de nulidad de la norma reglamentaria no comunica, sin más, sus efectos a los actos dictados en su aplicación; y más aún, cuando los mismos han alcanzado firmeza» (36). Con similar razonamiento, tampoco el TS ha admitido la revisión de oficio de sanciones tributarias impuestas al amparo de un Decreto que reguló el Estatuto de la Agencia Tributaria de Andalucía, anulado por el TSJ de esta Comunidad. Recopilando su jurisprudencia acerca de la anulación de disposiciones de carácter general el TS proclama de nuevo que «no cabe pues, fundar la nulidad de pleno derecho del acto considerando que la nulidad del mismo deriva de la nulidad de pleno derecho de las normas reglamentarias que le sirvieron de base» (37).

Por último conviene señalar que la nulidad de pleno derecho del reglamento ilegal que proclama el artículo 106.4 LPAC es compatible con la competencia jurisdiccional que reconoce la LJCA para fijar el alcance de la declaración de nulidad. Así se deduce de lo previsto en el artículo 71.1.a) de la LJCA cuando señala que la sentencia estimatoria «declarará no ser conforme a Derecho y, en su caso, anulará total o parcialmente la disposición o acto recurrido o dispondrá que cese o se modifique la actuación impugnada». Nótese, por tanto, que el órgano jurisdiccional tiene la posibilidad "en su caso" de anular total o parcialmente la disposición o acto recurrido, al igual que puede declarar o no la retroacción de actuaciones (a mi juicio, solo en beneficio del recurrente) o, incluso, como ha sucedido en alguna ocasión, posponer los efectos de su anulación a un momento posterior en casos absolutamente excepcionales (38). Asimismo procede recordar la singularidad de la previsión contenida en el artículo 19.2 TRLRHL conforme al cual cuando se declare la nulidad de una ordenanza fiscal «salvo que expresamente lo prohibiera la sentencia» -lo que implica un reconocimiento legal del margen de apreciación judicial de los efectos del fallo- se mantendrán los actos firmes o consentidos dictados al amparo de la ordenanza que posteriormente resulte anulada o modificada (39). Se trata, cierta-

(36) Vid., STS de 13 de diciembre de 2018, rec. 565/2017, ECLI:ES:TS:2018:4294.

(37) Vid., STS de 1 de abril de 2019, rec. 1187/2019, ECLI:ES:TS:2019:1079.

(38) Vid., entre otras, STS de 22 de abril de 2014, rec. 73/2013, ECLI: ES:TS:2014:1489.

(39) En el ámbito administrativo en general, y en el urbanístico en particular, la anulación de una disposición general trae consigo también como efecto la reviviscencia de la norma que la disposición anulada había derogado (por todas, STS de 8 de enero de 2015, rec. 4344/2012, 
mente, de un precepto atípico en tanto que contiene una norma procesal de atribución de competencias y porque aparentemente se aparta de la regla general contenida en los artículos 106.4 LPAC y 73 LJCA al ampliar la posibilidad al órgano jurisdiccional de fijar los efectos derivados de la anulación de una ordenanza fiscal (40). Pero también en esta línea se debería avanzar. Como sucede en otros sistemas de nuestro entorno (Francia, por ejemplo) cabría dar más poder a los órganos jurisdiccionales para modular los efectos de sus pronunciamientos de invalidez (admitiendo, por ejemplo, la anulación condicionada, la posibilidad de subsanación en el propio proceso, la conservación de los elementos no afectados por la invalidez o limitando simplemente la eficacia temporal y retroactividad de sus fallos) (41), margen de decisión discrecional que tampoco sería extraño en tanto que los órganos jurisdiccionales ya lo ejercen, por ejemplo, en el ámbito de las medidas cautelares.

\subsection{Efectos derivados de declaraciones de infracción del derecho europeo}

En los recursos por incumplimiento o infracción del derecho europeo (art. 263 TFUE) el TJUE «declarará nulo y sin valor ni efecto alguno el acto impugnado» e «indicará, si lo estima necesario, aquellos efectos del acto declarado nulo que deban ser considerados como definitivos» (art. 264 TFUE). En cambio, no existe una previsión similar cuando el TJUE resuelve una cuestión prejudicial (art. 267 TJUE) si bien él mismo ha establecido reiteradamente que es competencia exclusivamente suya limitar los efectos en el tiempo de sus sentencias y examinar previamente en cada caso si concurren los requisitos que exige su jurisprudencia para ello. Esto es, el TJUE «es el único que puede decidir acerca de las limitaciones en el tiempo que hayan de aplicarse a la interpretación que él mismo haya hecho de una norma del Derecho de la Unión» (42). Pues bien, es evidente que existe una notoria diferencia entre los pronunciamientos de infracción del derecho europeo respecto de los de inconstitucionalidad e invalidez de disposiciones generales. El TJUE dispone de un amplio margen para modular el alcance material de sus fallos -tanto para declarar expresamente contraria al derecho europeo una normativa nacional como para determinar el sentido en el que deba interpretarse ésta para ajustarse

ECLI:ES:TS:2015:81). Sin embargo, en el ámbito tributario, este efecto se traduce generalmente o bien en una vuelta al régimen tributario previo -cuando lo hubiera- o al general. Así, por ejemplo, la anulación de una ordenanza fiscal por incrementar inmotivadamente el tipo de gravamen de determinados bienes inmuebles, significaría que dichos inmuebles quedarán gravados con arreglo al régimen general. Lo mismo sucedería cuando, a consecuencia de la anulación de un planeamiento general, la calificación catastral de los inmuebles fuera otra (por todas, STS de 18 de junio de 2020, rec. 652/2018, ECLI:ES:TS:2020:1858). En otros casos, de producirse un vacío normativo por la anulación de una disposición reglamentaria habría de integrarse y valorarse en cada caso, atendidas diversas circunstancias, vid., STS de 23 de septiembre de 2019, rec. 408/2018, ECLI:ES:TS:2019:2877.

(40) $\mathrm{Al}$ respecto vid., Cunillera i Bosquets (2004) y Rodríguez Márquez (2004).

(41) Vid., Ruiz Palazuelos (2018) y Martín Rebollo (2019).

(42) Por todas, STJUE de 21 de marzo de 2000 (Gabalfrisa, S.L., C-110/98 a C-147/98) y STJUE de 4 octubre 2012 (Byankov, C-249/11) y, por todos, Cobreros Mendazona (2018) y Toledano Cantero (2019). 
al acervo comunitario- como para determinar su alcance temporal. Es más, frente a la tendencia a la prospectividad de los pronunciamientos de inconstitucionalidad e invalidez de disposiciones generales, el TJUE proclama con frecuencia la retroactividad de sus decisiones insistiendo en el carácter excepcional de la limitación de efectos de sus pronunciamientos (43), práctica que se ha intentado modificar por algunos estados miembros, partidarios en su mayoría de evitar los efectos ex tunc de sus pronunciamientos anulatorios (44). El TJUE ha insistido además en la obligación de los estados miembros de articular sistemas de revisión efectivos de actos administrativos que sean contrarios al derecho europeo cuando vulneren derechos atribuidos por el Ordenamiento jurídico europeo, cualquiera que sea la causa de su firmeza (45). A ello hay que sumar, además, que las infracciones del derecho europeo, por mor del efecto directo y primacía, no precisan de una sentencia comunitaria que declare formalmente esa infracción para provocar el deber de inaplicar una normativa nacional que contradiga la interpretación jurisprudencial del derecho europeo. De hecho, las sentencias del TJUE que estiman recursos por incumplimiento, aun teniendo carácter meramente declarativo, es decir, limitándose a constatar que el Estado miembro ha infringido el derecho de la Unión Europea, podrían afectar retroactivamente a los actos administrativos dictados en aplicación de la norma nacional contraria al derecho europeo (46). En definitiva, si bien la declaración del TJUE declarando la incompatibilidad de una norma nacional con el Derecho de la Unión no implica, siempre y en todo caso, su anulación o su invalidez (formal), sino en la mayoría de las ocasiones (supuestos de prejudicialidad) su mera inaplicación o invalidez (material), generalmente trae consigo la preceptiva revisión de todos los actos afectados y, a ser posible, con efectos ex tunc.

Ahora bien, esa revisión, en aplicación del "principio de autonomía procesal o procedimental", debe hacerse con arreglo a los mecanismos nacionales procurando, en todo caso, asegurar la equivalencia (respecto de actos dictados en infracción de una norma nacional) y la efectividad del pronunciamiento del TJUE (47). Y en este punto, lo que se aprecia es una imprecisa determinación del TJUE acerca de cuándo las técnicas nacionales de revisión de actos garantizan la efectividad del derecho europeo. De este modo, los efectos derivados de la invalidez de normas por infracción del derecho europeo se re-

(43) Prueba de ello, es que en la STJUE de 6 de octubre de 2005 (asunto C. 204/03), relativa a la limitación del derecho a deducir del IVA en caso de percepción de subvenciones, ante la petición del gobierno español de que el pronunciamiento del TJUE limitara sus efectos, este responde que «sólo con carácter excepcional puede el Tribunal de Justicia, aplicando el principio general de seguridad jurídica inherente al ordenamiento jurídico comunitario, verse inducido a establecerla».

(44) Vid., entre otros, González-Varas Ibáñez (2009).

(45) Vid., STJUE de 4 octubre 2012 (Byankov, C-249/11) y Fuentetaja Pastor (2018).

(46) $\mathrm{Al}$ respecto procede señalar que nuestro propio $\mathrm{TC}$ ha reconocido la naturaleza declarativa de las Sentencias del TJUE que resuelven recursos por incumplimiento no afecta a su fuerza ejecutiva conforme a su propia y reiterada jurisprudencia que abunda en la obligación de los órganos jurisdiccionales de los estados miembros y de la propia Administración de garantizar que dichas sentencias se lleven a efecto incluso eliminando las consecuencias pasadas del incumplimiento, STC 145/2012, de 2 de julio. Sobre los efectos de la jurisprudencia del TJUE vid., por todos. Vid., Iranzo Cerezo (2020), Nuñez Lozano (2017) y Cobreros Mendazona (2016).

(47) Vid., con más detalle, referido al ámbito tributario, Sesma Sánchez (2017) y desde una perspectiva más general Fuentetaja Pastor (2018). 
conducen a los derivados de la invalidez de normas nacionales por inconstitucionalidad o ilegalidad, con las mismas restricciones que se analizan seguidamente para intentar la revisión de un acto firme "nacional" lo que significa que la nulidad de pleno derecho, la revocación, el recurso extraordinario de revisión y la devolución de ingresos indebidos tienen escaso margen de éxito cuando se trata de revisar actos firmes dictados en infracción del derecho europeo. De ahí que en estos casos se recurra con frecuencia a la llamada tutela secundaria, esto es, al régimen de responsabilidad patrimonial del Estado legislador por infracciones del derecho europeo (art. 32 LRJSP) al que nos referimos en el último epígrafe.

Por otra parte, al igual que pusimos de manifiesto con los pronunciamientos de inconstitucionalidad, también el artículo 32.6 de la LRJSP ha "interferido" en la competencia del Tribunal europeo al proclamar que "La sentencia que declare la inconstitucionalidad de la norma con rango de ley o declare el carácter de norma contraria al Derecho de la Unión Europea producirá efectos desde la fecha de su publicación en el "Boletín Oficial del Estado" o en el "Diario Oficial de la Unión Europea", según el caso, "salvo que en ella se establezca otra cosa"». Como señalamos entonces, aparte de las dudas que arroja que una norma de derecho nacional interfiera en la regulación de los efectos de una sentencia europea, es cierto que este inciso deja aparentemente intacta la competencia del TJUE para "establecer otra cosa" en materia de efectos, pero la cuestión es que si el TJUE no lo hiciera, es decir, tampoco se pronunciara sobre el alcance de sus pronunciamientos (lo que sucede con relativa frecuencia en las cuestiones prejudiciales), este precepto "nacional" vendría a consagrar los efectos prospectivos de los fallos del TJUE ("desde su publicación en el Diario Oficial de la Unión Europea") en contra de la propia jurisprudencia europea que predica la eficacia retroactiva de sus pronunciamientos.

\section{ALTERNATIVAS DE REVISIÓN DE LOS ACTOS TRIBUTARIOS DICTADOS AL AMPARO DE NORMAS INVÁLIDAS}

A pesar del margen de que disponen los órganos jurisdiccionales para determinar el alcance material y temporal de sus sentencias anulatorias (particularmente amplio en el caso del TJUE), como hemos señalado, la regla general es, bien por disposición legal bien por práctica reiterada, la intangibilidad de los actos firmes dictados al amparo de una norma inválida. No existe, además, en nuestro ordenamiento un precepto que establezca la nulidad sobrevenida de un acto ya firme por haberse anulado la norma que le daba cobertura (48).

(48) Conviene advertir, no obstante, que el TS ha legitimado recientemente con carácter excepcional la impugnación indirecta de valores catastrales firmes, inválidos sobrevenidamente por diversas circunstancias (anulación de planeamiento, y también de ponencias de valores o por la repercusión de la interpretación jurisprudencial de una categoría de suelo) a través de la impugnación ordinaria de las liquidaciones del IBI y del IIVTNU. Ciertamente, en estos casos, no se está impugnando el acto de valor catastral ya firme por invalidez de la norma de cobertura (caso de la anulación de planes urbanísticos), pero indirectamente, a través de la impugnación ordinaria de las liquidaciones del IBI o del IIVTNU que toman como referencia aquel como elemento de cuantificación, se consigue trasladar la invalidez de la norma al acto aunque, como digo, esta 
Nuestro sistema de revisión de actos tributarios revela que la invalidez de la norma no está tipificada ni como causa de nulidad de pleno derecho, ni como causa de revocación, ni como supuesto que legitime la devolución directa de ingresos indebidos, ni como documento de valor esencial a los efectos de instar un recurso extraordinario de revisión. $\mathrm{Al}$ mismo tiempo, procede señalar que la invalidez de un acto no se presume, antes el contrario, lo que se presume es su validez y legalidad mientras una resolución administrativa o jurisdiccional no declare formalmente su anulación (49).

Lo anterior significa que quien resulte afectado por una norma inválida (sea por inconstitucionalidad, infracción del derecho europeo o ilegalidad) debe acudir a las posibilidades de revisión de los actos tributarios que, ciertamente, constituyen un cauce rígido sometido a plazos de caducidad breves (caso de impugnación de liquidaciones tributarias) y a causas tasadas y de interpretación restrictiva cuando se trata de sistemas extraordinarios de revisión de actos firmes algunos de los cuales, además, no pueden ejercitarse "plenamente" a instancia de parte. Subsidiariamente, desde la aprobación de la Ley 40/2015, cabe la posibilidad de instar (no como mecanismo de revisión de un acto firme) la responsabilidad patrimonial del Estado legislador en los supuestos de infracción de inconstitucionalidad y de derecho europeo (art. 32 LRJSP), que presentan importantes limitaciones desde la perspectiva procesal, temporal y material o, en el caso de ejercitar la responsabilidad frente a la Administración autora de una norma reglamentaria ilegal, en aplicación del artículo 106.4 LPAC instarla en el plazo de un año desde la anulación de la disposición. A estas alternativas de revisión de actos firmes dictados al amparo de una norma inválida o de reparación de los daños y perjuicios ocasionados por su aplicación me refiero seguidamente.

\subsection{La acción de nulidad de pleno derecho}

La acción de nulidad de pleno derecho de los actos tributarios firmes dictados al amparo de una norma inválida ha sido la principal vía (primaria) para perseguir la retroactividad ex tunc y plena de las declaraciones de inconstitucionalidad y de las referidas a infracciones del derecho europeo. Y lo ha sido con base en la invocación del dogma clásico de que la invalidez de la norma es radical y con efectos ex tunc de modo que también los actos dictados al amparo de estas normas serían igualmente nulos de pleno derecho desde su origen (50). Mientras el Consejo de Estado (51) y otros órganos consultivos auto-

opción solo cabe a través de la impugnación de "liquidaciones vivas", en ningún caso, de las que ya fueran firmes. Al respecto vid., en particular y entre otras, la STS de 19 de febrero de 2019, rec. 128/2016, ECLI:ES:TS:2019:579, 4 de marzo de 2019, rec. 11/2017, ECLI: ES:TS:2019:804, 30 de enero de 2020, rec. 3412/2018, ECLI:ES:TS:2020:228 y de 22 de junio de 2020, rec. 3446/2017, ECLI:ES:TS:2020:1882. Un análisis de esta novedosa jurisprudencia en Sesma Sánchez (2020) y Marín-Barnuevo Fabo (2020).

(49) Vid., con más detalle Sesma Sánchez (2017). De hecho, como señala la doctrina administrativa, la supuesta distinción entre pronunciamientos declarativos de la nulidad y constitutivos de la anulabilidad es errónea y carece de fundamento, vid., Cano Campos (2017).

(50) Entre los trabajos más recientes defensores de esta posición vid. Ruiz Zapatero (2006), Moreno Fernández (2009), Ruiz Almendral (2018) y García Moreno (2020). En contra de esta postura vid., Sesma Sánchez (2017).

(51) Entre otros muchos, vid., Dictamen 23/2010, de 14 de abril, con relación a la revisión de 
nómicos al dictaminar las revisiones de oficio han sostenido que la inconstitucionalidad de la norma no convierte en nulo de pleno derecho de forma automática al acto dictado bajo su amparo (52), la posición del TS ha sido vacilante hasta fechas recientes. En efecto, si bien en diversas sentencias referidas al ámbito tributario mantuvo como criterio tradicional el de incomunicación del grado de invalidez de la disposición general declarada nula a los actos firmes dictados en aplicación de la misma al no estar tipificada como causa de nulidad radical del acto la inconstitucionalidad de la norma que lo ampara (53), hubo pronunciamientos que, en el marco de la elaboración jurisprudencial de la responsabilidad patrimonial del Estado legislador con ocasión de la inconstitucionalidad del gravamen complementario de la tasa fiscal sobre el juego, sostuvieron lo contrario respecto de aquellos supuestos en los que el TC no hubiera formulado pronunciamiento alguno sobre la eficacia retroactiva de la declaración de inconstitucionalidad (54).

oficio de tarifas portuarias.

(52) Vid., a título de ejemplo, el Dictamen 65/2019, de 1 de marzo del Consejo Consultivo del Principado de Asturias.

(53) Vid., un análisis más detallado de la evolución de esta jurisprudencia del Tribunal Supremo en Sesma Sánchez (2017).

(54) Así lo sostuvo ocasionalmente el TS entre otras, en la STS de 15 de julio de 2000, rec. 736/1997, ECLI:ES:TS:2000:5880 y en la de 2 de junio de 2010, rec. 588/2008, ECLI:ES:TS:2010:3898 -del Pleno de la Sala de lo Contencioso-Administrativo con relación a la controvertida tesis de la responsabilidad patrimonial del Estado legislador, sentencia que cuenta con once votos particulares- en la que el TS afirmó que la contravención entre una la Constitución y una Ley o norma con fuera de Ley significa la nulidad de los preceptos impugnados, una nulidad radical o de pleno derecho que se retrotrae al momento mismo en el que entró en vigor la norma ilegal, pronunciamiento que, en todo caso, se formuló como obiter dicta en el contexto de apreciar o no la responsabilidad del estado legislador por una norma inconstitucional. En otros casos, sin embargo, posteriores, como en la STS de 16 de noviembre de 2016 (recurso 1590/2015, ECLI:ES:TS:2016:4979) el TS consideró que no procedía la revisión de liquidaciones firmes a raíz de la inconstitucionalidad de la norma de cobertura porque tendría "grave incidencia sobre principios básicos como el de seguridad jurídica y categorías jurídicas como el acto firme, puesto que siguiendo la teoría de la sentencia de instancia la firmeza de los actos se haría depender de futuras declaraciones de constitucionalidad o conformidad con el ordenamiento europeo de la legislación que sirvió de soporte al acto». También en esta línea se ha pronunciado el TS en las SSTS de 13 de junio de 2016 (recurso 2640/2015 ECLI:ES:TS:2016:2690), de 20 de octubre de 2016 (recurso 2588/2015, ECLI:ES:TS:2016:4676,) y de 22 de noviembre de 2016 (recurso 2744/2015 ECLI:ES:TS:2016:5188).

Es más, aunque en un primer momento, cuando el TC optó por la prospectividad de sus fallos, el TS criticó lo que consideraba una interpretación extensiva del art. 40.1 LOTC, ya en la STS de 26 de diciembre de 1998, dictada en interés de Ley (rec. 7213/1998, ECLI:ES:TS:1998:7917) había declarado que la doctrina de la citada STC 45/1989 tenía alcance general y que resultaba aplicable a otras declaraciones de inconstitucionalidad aunque no hubiera sido reiterada por el TC en una sentencia concreta. Y en fallos posteriores, como los relativos a la inconstitucionalidad de las tarifas portuarias (vid., por todas, entre otras, muchas, STS de 5 de marzo de 2008, rec. 22/2007, ECLI:ES:TS:2008:1115), el TS consideró que, por exigencias del principio de seguridad jurídica, la nulidad por vía de inconstitucionalidad de una Ley no se traslada al acto administrativo si éste ya es firme o está confirmado por sentencia judicial firme y no puede ser objeto de revisión. Al respecto, vid., Sesma Sánchez (2017). 
Al hilo, sin embargo, de la reciente controversia sobre la interpretación del fallo de la STC 59/2017, con relación al IIVTNU, el TS parece haber zanjado definitivamente la cuestión en las recientes sentencias de 6 de marzo de 2020 (rec. 5923/2018, ECLI: ES:TS:2020:722) y de 18 de mayo de 2020 [rec. 1665/2019 (ECLI:ES:TS:2020:973), rec. 2596/2019 (ECLI:ES:TS:2020:970) y rec. 1068/2019 (ECLI:ES:TS:2020:984)]. En efecto, en estos fallos el TS, tras recordar su jurisprudencia reiterada acerca del carácter extraordinario de la revisión de oficio por nulidad de pleno derecho, de la interpretación restrictiva de las causas de nulidad en beneficio de la seguridad jurídica y de la prohibición de emplear la acción de nulidad cuando se trata de causas de anulabilidad, ha señalado no solo que la inconstitucionalidad de la norma no está tipificada como causa de nulidad de pleno derecho del acto sino que tampoco, en el caso particular, examinado, las liquidaciones incurrían en ninguna otra de las tipificadas en el artículo 217 LGT considerando:

$\left.1^{\circ}\right)$ Que no concurre la causa referida a la lesión de derechos y libertades fundamentales (art. 217.1.a) LGT), porque la inconstitucionalidad (parcial y condicional) del IIVTNU se fundamentó en el principio de capacidad económica que no constituye un derecho susceptible de amparo constitucional.

$2^{\circ}$ ) Que no concurre la causa de ausencia total y absoluta del procedimiento legalmente establecido (art. 217.1.e) LGT) -en tanto que el contribuyente no podía probar una minusvalía- porque el procedimiento aplicado fue el legalmente aplicable en ese momento y deducir que debiera haber sido otro el seguido "supondría no ya solo proyectar hacia atrás esa declaración de nulidad sino, sobre todo, construir retrospectivamente un procedimiento con un trámite (la eventual prueba de inexistencia de minusvalía) que no podía ser omitido por la Hacienda municipal por la razón esencial de que "no estaba previsto legalmente" esto es, no estaba contemplado en la Ley reguladora del procedimiento que debía seguirse para liquidar».

$3^{\circ}$ ) Que tampoco concurre la causa de nulidad referida a la adquisición de facultades o derechos (art. 217.1.f) LGT) cuando se carezca de los requisitos esenciales para su adquisición porque el precepto sanciona los actos dictados declarativos de derechos "dictados por la Administración" cuando es el particular el que carece de los requisitos esenciales para ello y no cuando es la Administración la que supuestamente no tiene derecho a cobrar o exigir el importe de la liquidación.

$\left.4^{\circ}\right) \mathrm{Y}$, por último, que no resulta aplicable tampoco la causa de nulidad referida a cualesquiera otra que se establezca expresamente en una disposición legal (art. 217.1.g) LGT) porque ni por esta vía cabe invocar la aplicación del artículo 47.2 LPAC (nulidad de pleno derecho de disposiciones generales) puesto que estamos ante un acto administrativo, ni tampoco una interpretación expansiva del artículo 39.1 LOTC que únicamente declara la nulidad por inconstitucionalidad de los preceptos impugnados cuando así lo declare la sentencia de inconstitucionalidad, pero no se refiere a los actos dictados bajo su amparo y, además, en el caso controvertido, la sentencia 59/2017 declaró la inconstitucionalidad parcial y condicionada (no absoluta) de los artículos 107.1 y 107.2 TRLRHL, lo que significa su constitucionalidad en aquellos casos en los que pueda acreditarse el incremento de valor. 
En definitiva, como señalamos en su momento y ha confirmado el TS, «no existe ningún precepto expreso, contenido en una norma con rango de ley que tipifique o establezca que la nulidad -por inconstitucionalidad- de un precepto legal.... (que) determine la nulidad de éste cuando el mismo ha ganado firmeza en vía administrativa» y "si los supuestos legales de nulidad radical deben ser objeto -como dijimos más arriba- de interpretación estricta, la aplicación de la letra g) del artículo 217 de la Ley General Tributaria exigiría, cuando menos, que una norma con rango de ley señalara con claridad que la declaración de inconstitucionalidad de un precepto legal acarrea la nulidad radical de los actos dictados a su amparo, norma que -como dijimos- no aparece en nuestro ordenamiento jurídico» (55).

En el caso de disposiciones generales anuladas, tampoco el TS ha admitido la revisión de oficio de los actos firmes afectadas por ellas. Así lo proscribe expresamente el artículo 73 de la LJCA (y el art. 19.2 TRLHL para el ámbito local con relación a la invalidez de ordenanzas fiscales) y así lo viene afirmando el TS, en este caso sin fisuras en su doctrina, para quien el grado de invalidez de los actos administrativos singulares es consecuencia de las circunstancias que concurren en su génesis, sin que exista transferencia o traslación del grado de invalidez (nulidad de pleno derecho) de la disposición general a los actos singulares de aplicación. Incluso en el supuesto en el que la invalidez de la norma afectara a la competencia del órgano que ha dictado el acto, tampoco se ha apreciado una nulidad radical del mismo por incompetencia manifiesta del órgano (art. 217.1.b) LGT) (56). Así, por ejemplo, el TS ha considerado que habiéndose anulado el Estatuto del personal del órgano liquidador de la Agencia Tributaria de Andalucía no cabía invocar la nulidad manifiesta del órgano liquidador para invalidar sanciones tributarias firmes porque «en modo alguno estamos ante una incompetencia material ni territorial, habiéndose anulado el Decreto por una causa formal, siendo relevante que cuando se dictó el acto sancionador por el órgano actuante, dicho Decreto propiciaba su correcto actuar, lo cual descarta una incompetencia material manifiesta, como exige el art. 217.1.b) LGT» (57).

En el supuesto de infracciones del derecho europeo, después de algunos pronunciamientos contradictorios, con ocasión de la repercusión de la STJUE de 3 de septiembre de 2014, C-127/12, referida a la incompatibilidad con el derecho europeo del régimen de tributario de los no residentes en el ISD frente a los residentes, llama la atención que el TS haya señalado recientemente (SSTS de 16 de julio de 2020, rec. 810/2019, ECLI:ES:TS:2020:2724 y 4344/2019, ECLI:ES:TS:2020:2701) que tal pronunciamiento europeo, si bien no constituye por sí mismo, motivo suficiente para declarar la nulidad de cualesquiera actos, "sí obliga, incluso en presencia de actos firmes, a considerar la petición de revisión sin que haya de invocarse para ello una causa de nulidad de pleno derecho porque es la única posibilidad de satisfacer el principio de efectividad en el caso planteado (liquidación girada a un sujeto pasivo no residente en España por el Impuesto sobre Sucesiones y Donaciones)» (58). A lo

(55) Vid., SSTS de 18 de mayo de 2020, antes citadas.

(56) Vid., Sesma Sánchez (2017).

(57) Vid., STS de 1 de abril de 2019, rec. 440/2019, ECLI:ES:TS:2019:1079.

(58) El ATS de 17 de octubre de 2019 que dio lugar a esta sentencia señalaba como cuestiones casacionales: «Determinar si la doctrina del TJUE contenida en la sentencia de 3 de septiembre de 
anterior, el TS añade que el principio de buena administración puede imponer a la Administración el deber de anular de oficio una liquidación que se sabe, cuando se dictó, amparada en una norma sospechosa de infringir el derecho europeo en un proceso judicial ante el TJUE. De este modo, el TS acude a una generosa interpretación del principio de efectividad del derecho europeo considerando que resulta excesivamente rígido exigir a un no residente la impugnación en plazos de caducidad tan breves de liquidaciones afectadas por procesos judiciales europeos en los que se ventilaba la posible infracción del derecho nacional y desconocidos por el particular afectado, máxime en un supuesto que el TS califica de «norma clara y flagrantemente discriminatoria entre ciudadanos de diferentes estados miembros». Y al mismo tiempo avanza en una interpretación menos rígida y flexible de las causas de nulidad del artículo 217 LGT señalando «la nulidad de pleno derecho de una liquidación girada a un sujeto pasivo no residente en España, por el Impuesto sobre sucesiones, en aplicación de una ley declarada no conforme al Derecho de la Unión Europea, que es firme por haber sido consentida por éste antes de haberse dictado aquella sentencia" y precisando expresamente que «en este caso la liquidación adolece de nulidad de pleno derecho, en virtud de la causa prevista en la letra a) del mencionado precepto, referida a los actos “a) Que lesionen los derechos y libertades susceptibles de amparo constitucional, pues no otro efecto cabe aplicar a un acto administrativo basado en una ley que, al margen de su evidente contravención del Derecho de la Unión Europea, consagra una situación de diferencia de trato discriminatoria entre los residentes y los no residentes (con quebrantamiento del artículo 14 de la $\mathrm{CE}$ ) en cuanto al régimen de beneficios fiscales previstos para los primeros por razón de residencia”. Debe advertirse, no obstante, que en ningún momento el TS utiliza el argumento de que la sentencia europea que declaró el incumplimiento de nuestro país fuera por sí misma la causa de nulidad radical del acto firme. Lo que resolvió es que, en este caso, el acto mismo incurría en una causa de nulidad ya tipificada [art. 217.1.a) LGT]. Apurando así la interpretación de esta causa de nulidad, el TS da cabida en la misma en este relevante fallo a la infracción del derecho a la igualdad tributaria que lo adscribe al artículo $14 \mathrm{CE}$, y no al artículo $31 \mathrm{CE}$, considerándolo además un "derecho fundamental europeo" en el Tratado de Funcionamiento de la Unión Europea (art. 63) (59) al tiempo que garantiza de este modo el principio de efectividad del derecho europeo tal y como se interpreta "expansivamente" por el propio TJUE (60).

\footnotetext{
2014 asunto Comisión/España (C 12712 constituye, por sí misma, motivo suficiente para declarar, en interpretación del artículo 2171 LGT, la nulidad de pleno derecho de una liquidación girada a un sujeto pasivo no residente en España, por el Impuesto sobre sucesiones, en aplicación de una ley declarada no conforme al Derecho de la Unión Europea, que es firme por haber sido consentida por éste antes de haberse dictado aquella sentencia» y, "En caso de que se diera a la pregunta formulada una respuesta afirmativa, habilitante de esa posibilidad, sería necesario dilucidar en virtud de qué título jurídico, esto es, de qué causa legal de nulidad radical o de pleno derecho de las tipificadas numerus clausus en el mencionado artículo 2171 LGT, operaría y, además, con qué limitación temporal».
}

(59) Vid., García Moreno (2020).

(60) Vid., Fuentetaja Pastor (2018). 


\subsection{La revocación de actos firmes dictados al amparo de una norma inválida}

La revocación tributaria en los términos regulados en el artículo 219 de la LGT no permite, a mi juicio, postular con carácter general que resulte admisible como cauce de anulación de actos tributarios firmes dictados al amparo de una norma inválida (61). Y no la considero un cauce válido, insisto a priori y en línea de principio, por varios motivos. En primer lugar, porque a diferencia de lo que sucede con la revocación de los actos administrativos regulada en el artículo 109 LPAC, la tributaria es más restrictiva desde el momento en que el legislador no la contempla en términos de oportunidad, sino que acota legalmente las causas de revocación. Causas que, como es sabido y tratándose de sistemas de revisión de oficio, deben interpretarse de forma restrictiva para salvaguardar la seguridad jurídica y la estabilidad de los actos que disciplina las relaciones jurídicas entre la Administración y los administrados aunque ello no impide, precisamente por tratarse de causas regladas, el control jurisdiccional de su adecuada interpretación y aplicación al caso particular (62).

En segundo lugar, porque ninguna de las causas que se enumeran en el artículo 219 LGT se refiere expresamente al supuesto que nos ocupa -invalidez de la norma- y entiendo, además, que tampoco procedería su tipificación legal como tal porque supondría una clara interferencia en la competencia de los órganos jurisdiccionales para fijar el alcance de sus fallos (63).

En tercer lugar, porque admitir con carácter general la revocación de los actos firmes dictados al amparo de una norma anulada ocasionaría una inseguridad jurídica y podría resultar contraria al principio de igualdad -uno de los límites establecidos a la revocación tributaria en el artículo 219.1 LGT- al permitir la anulación de actos firmes, pero no la de los actos que hubieran sido recurridos en vía económico administrativa o jurisdiccional que están excluidos legalmente de la posibilidad de revocación (64).

Por último, porque sostener que la causa de "infracción manifiesta de la Ley" incluye a las infracciones constitucionales, dejaría absurdamente fuera a las infracciones de derecho europeo lo que, además, supondría una exclusión contraria al principio de

(61) Vid., Sesma Sánchez (2017).

(62) Vid., STS de 19 de febrero de 2014, recurso 216/1997, ECLI:ES:TS:2014:1189. Al respecto procede señalar que el Consejo de Estado se ha referido a la potestad revocatoria como totalmente discrecional pues está sujeta a causa y límites y, aunque sus perfiles son indeterminados (por ejemplo, frente a la alternativa de la revisión de oficio) y arrojen reservas su escaso marco procedimental (puesto que no está prevista la audiencia del interesado ni el Dictamen de un órgano consultivo), también ha señalado que no existe a disposición del particular una acción revocatoria en términos semejantes a aquellos en los que se configura la acción de revisión de oficio. Lo que sí existe es el derecho (genérico) a la presentación y tramitación de las solicitudes que insten los administrados, cfr. Collado Martínez (2018).

(63) Si la invalidez de la norma, por ejemplo, por inconstitucionalidad o infracción del derecho europeo estuviera tipificada como causa de revocación es evidente que se perjudicaría la competencia y facultad de los órganos jurisdiccionales de fijar los efectos de sus pronunciamientos de invalidez. Por lo mismo, en ningún caso la ilegalidad de una norma reglamentaria podría operar como causa de revocación por contravenir expresamente lo previsto en el artículo 73 LJCA.

(64) Con más detalle Sesma Sánchez (2017). 
equivalencia. Además, en su literalidad estricta, la norma se refiere a infracciones "manifiestas" de un acto "respecto de la Ley" que lo ampara, no a infracciones (por inconstitucionalidad o violación del derecho europeo) de la propia Ley. Es evidente, además, que dicha causa solo debiera abarcar infracciones "manifiestas" del acto respecto de la Ley que lo ampara, lo cual difícilmente puede apreciarse cuando se trata de vicios de inconstitucionalidad o infracciones de derecho europeo que rara vez pueden tildarse de "manifiestos" o, por utilizar la analogía propia del derecho europeo, "suficientemente caracterizados". De hecho, procede señalar que ni la AN ni el TS han apreciado esta causa cuando se trataba, por ejemplo, de liquidaciones giradas al amparo de normas que infringían el derecho europeo (como ha sucedido con las tasas de las operadoras de telefonía móvil) (65).

Ahora bien, es cierto que la causa de revocación referida a la aparición de "circunstancias fácticas o jurídicas sobrevenidas" -que implícitamente acoge cierta discrecionalidad en la decisión administrativa de revocar aunque en todo caso ha de ser motivada si es denegatoria- ha favorecido la interpretación doctrinal de que, entre ellas, pudiera tener cabida precisamente la invalidez de la norma de cobertura porque la literalidad del precepto hace referencia a que dichas circunstancias hagan "improcedente" el acto a revisar, sin mencionar su posible ilegalidad (66). De hecho, actualmente está admitida la cuestión casacional que plantea, no solo la posibilidad de una "revocación jurisdiccional", acordada por el órgano jurisdiccional en contra del criterio de la Administración (67),

(65) De hecho el TS, al tiempo de analizar si cabía la revocación de la Tasa General de Operadores de telefonía móvil por infracción del derecho europeo, señaló que en este caso «no es un dato intrínsecamente presente en la liquidación misma y que revele de modo patente y originario la contravención legal con evidencia, de forma inherente, toda vez que la sedicente ilegalidad sólo la podría aportar una actividad probatoria posterior a la liquidación misma», vid., STS de 22 de noviembre de 2016, rec. 3756/2015, ECLI:ES:TS:2016:5189.

(66) Entre otros vid., García Novoa (2005) y Martínez Muñoz (2006). También algunos órganos jurisdiccionales han admitido esta interpretación. Vid., entre otras, SSTSJ de Murcia, de 30 de diciembre de 2010, rec. 740/2009, ECLI: ES:TSJMU:2010:2794 y de 29 de junio de 2011, rec. 864/2006, ECLI: ES:TSJMU:2011:1677 y de 28 de septiembre de 2011, rec. 748/2006, ECLI: ES:TSJMU:2011:2293.

(67) En concreto, la cuestión es «determinar, interpretando conjuntamente los artículos 219 de la Ley General Tributaria y 72.2 y 73 de la Ley de la Jurisdicción Contencioso-Administrativa, si el órgano judicial puede sustituir a la Administración competente, en sentencia, acordando la procedencia de una solicitud de revocación -y accediendo a esta- presentada por un particular contra un acto de aplicación de un tributo o si, por el contrario, debe limitarse, caso de considerar disconforme a derecho la decisión recurrida, a ordenar la tramitación del procedimiento al órgano competente por ser atribución exclusiva de la administración la incoación y la decisión del procedimiento de revocación» (ATS de 23 de julio de 2020, rec. 7052/2019). En mi opinión, con el máximo respeto al futuro pronunciamiento del TS, entiendo que no cabe la posibilidad de acordar la revocación en sede jurisdiccional, en contra del criterio de la Administración, puesto que la facultad está reservada "legalmente" a la Administración. Ahora bien, ello no impediría, en mi opinión, que el propio órgano jurisdiccional pudiera (en el caso de pronunciamientos de inconstitucionalidad o recursos directos contra disposiciones generales) ordenar en su fallo, como contenido mismo de su pronunciamiento, la revocación -en tanto que anulación- de los actos firmes afectados por la invalidez de la norma en el marco temporal que estimara en caso de apreciar alguna de las causas legales de revocación. Fuera de este caso, entiendo que del mismo modo que se controla jurisdiccionalmente 
sino precisamente «determinar si la anulación sobrevenida, por sentencia, de la norma que ampara la exacción constituye un motivo válido para acceder a la revocación de una liquidación firme ex artículo 219 de la Ley General Tributaria» (68) y si "para reconocer ese derecho (a la revocación) puede ampararse el órgano sentenciado en la nulidad de un precepto constitucional, haciendo así derivar efectos ex tunc de una sentencia del Tribunal Constitucional publicada después de haber adquirido firme a las liquidaciones tributarias litigiosas» (69).

\subsection{La devolución de ingresos indebidos}

Cuando la obligación tributaria afectada por la declaración de invalidez de la norma que la ampara se hubiera gestionado mediante autoliquidación, lo que procede es acudir a la rectificación de la misma para así obtener la devolución del ingreso indebido al amparo de los artículos 120.3 y 221.4 LGT y 126 del RGGI. A tal efecto, cuatro consideraciones resultan especialmente relevantes:

$1^{\text {a }}$. Es una vía válida solo para recuperar ingresos tributarios indebidos, lo que podría cuestionarse, por ejemplo, en el caso de pagos fraccionados indebidos que pudieron ser regularizados a través de una autoliquidación posterior (70).

las decisiones de inadmisión de solicitudes de revisión de oficio, también debe someterse a revisión jurisdiccional la negativa de la Administración a examinar si concurren las causas de revocación pero sin alcanzar a sustituir la facultad revocatoria que legalmente solo compete a la Administración por una supuesta facultad revocatoria jurisdiccional. De hecho, así lo ha sostenido en otras ocasiones, vid., STS de 19 de febrero de 2014, recurso 216/1997, ECLI:ES:TS:2014:1189.

(68) Vid., ATS de 23 de julio de 2020, rec. 7052/2019, referido a los efectos de la anulación de una Orden Ministerial que afectaba al reconocimiento de la exención en el ICIO de determinadas obras realizadas en el Museo Diocesano sito en el Palacio Arzobispal de Zaragoza. Al anularse dicha Orden, el Arzobispado solicitó el reconocimiento de la exención y la consiguiente devolución del impuesto a través de la revocación, petición que fue desestimada por el Ayuntamiento pero admitida por el JCA que declaró la procedencia de la revocación considerando que le está permitido a un órgano jurisdiccional resolver sobre la decisión de fondo. A partir de este conflicto se plantea la cuestión casacional citada.

(69) Vid., AATS de 11 de abril de 2019, rec. 126/2019, de 9 de mayo de 2019, rec. 442/2019 y ATS de 9 de mayo de 2019, rec. 442/2019, referidas a la posible revocación jurisdiccional de liquidaciones firmes de la plusvalía. Esta última cuestión casacional trae causa de una STJCA número 6 de Valencia de 20 de noviembre de 2018 (rec. 404/2018) que, ante liquidaciones firmes del IIVTNU, afectadas por la STC 59/2017, de 11 de mayo, consideró que, excluida la vía del recurso extraordinario de revisión y la rectificación de errores, cabía la posibilidad de revisar las liquidaciones firmes por vía de la revisión de actos nulos de pleno derecho y la revocación y, con relación a esta, consideraba que la Administración está obligada a tramitar y proceder a su examen cuando se insta por el particular, pero no a desestimarla sin más, porque no es admisible que la decisión de la Administración sea enteramente discrecional y que la decisión o no de revocar esté exenta del control jurisdiccional.

(70) Tras la declaración de inconstitucionalidad (STC 78/2020, de 1 de julio) del Real Decreto Ley 2/2016, de 30 de septiembre, que incrementó el sistema de pagos fraccionados se ha planteado la cuestión de si cabe instar la devolución de los pagos ingresados "de más" aunque, con posterioridad, su "inconstitucional" exceso ya se hubiera regularizado al ingresar una cuota tributaria 
$2^{\text {a }}$ La rectificación se debe instar en el plazo de cuatro años desde que se realizó el ingreso indebido (art. 126. 2 RGGI), no siendo admisible situar el dies a quo en la fecha de publicación de la sentencia que declaró la invalidez de la norma (71).

$3^{\text {a }}$. Esta opción no es admisible como vía inmediata o directa para recuperar lo ingresado al amparo de una liquidación tributaria si no se ha instado previamente su revisión y anulación. En efecto, si la liquidación ya es firme, de conformidad con lo previsto en el artículo 221.3 LGT «únicamente se podrá solicitar la devolución del mismo instando o promoviendo la revisión del acto mediante alguno de los procedimientos especiales de revisión establecidos en los párrafos a), c) y d) del artículo 216 de la LGT y mediante el recurso extraordinario de revisión». A pesar de que existen algunos pronunciamientos jurisprudenciales que han admitido la posibilidad de instar directamente la devolución de ingresos indebidos respecto de liquidaciones firmes en supuestos en los que se ha declarado la invalidez de la norma de cobertura -especialmente en los casos de inconstitucionalidad e infracción del derecho europeo, no así en los casos de ilegalidad de una norma reglamentaria- (72), como ha señalado recientemente el TS, reiterando su doctrina al respecto, «el apartado del artículo 221 LGT responde al principio de seguridad jurídica impidiendo que se reabran a través de un nuevo procedimiento, en este caso de devolución de ingresos indebidos, pretensiones que no habían sido ejercitadas en el momento procesal oportuno» (73). Por tal motivo ha declarado que no es posible una devolución directa automática de un gravamen declarado inconstitucional sino que tal devolución debe solicitarse necesariamente a través de alguno de los procedimientos señalados en el artículo 221.3 LGT.

$4^{\circ}$. Esta vía de revisión ha sido particularmente controvertida cuando la devolución se insta por infracciones del derecho europeo ya que el TJUE viene señalando, con carácter general, que «el derecho a obtener la devolución de los impuestos percibidos en un Estado miembro infringiendo el Derecho la Unión es la consecuencia y el complemente de los derechos conferidos a los contribuyentes por las disposiciones del Derecho de la Unión, tal como han sido interpretados por el Tribunal de Justicia. Por lo tanto, en principio, un Estado miembro está obligado a devolver los impuestos

más baja en la autoliquidación. A mi juicio, en estos casos, la única pretensión legítima sería la de reclamar los intereses de demora de los excesos pagados entre octubre de 2016 y abril de 2018 y, a tal efecto, la devolución de ingresos indebidos (en plazo aún) podría operar para su recuperación. Debe advertirse, además, que el TC ha rechazado ahondar en la interpretación de si las "situaciones consolidadas" inatacables conforme a su fallo incluyen las autoliquidaciones cuya revisión no fue instada hasta la publicación de la sentencia, vid., ATC de 21 de julio de 2020.

(71) Vid., entre otras, STC 105/2009, de 4 de mayo y especialmente, STS de 18 de enero de 2005, recurso (26/2003), ECLI:ES:TS:2005:96.

(72) Con más detalle, Sesma Sánchez (2017). También sobre el tema vid. Palao Taboada (1995) y, con relación a esta figura vid., por todos, Eseverri Martínez (2018).

(73) Vid., STS de 11 de junio de 2015, recurso 1801/2012, ECLI:ES:TS:2015:2713 y, con relación a la improcedencia de la devolución de ingresos indebidos respecto de liquidaciones firmes de la plusvalía sin haber instado previamente su anulación STS de 6 de marzo de 2020, rec. 5923/2018, ECLI: ES:TS:2020:722. 
recaudados en contra de lo dispuesto en el Derecho de la Unión» (74). Sin embargo, amén de que no es un criterio consolidado ya que el TJUE ha limitado en ocasiones retroactivamente el alcance temporal de sus fallos -aunque ciertamente es reacio a ello (75)-, el TS ha considerado, con relación a esta jurisprudencia comunitaria, que en aplicación del principio de autonomía procesal la devolución de ingresos tributarios indebidos realizados al amparo de una norma tributaria contraria al derecho europeo debe ejercerse con arreglo a las reglas nacionales de este cauce revisor lo que significa, en particular, que solo cabe la devolución de ingresos autoliquidados (no de cantidades ingresadas mediante liquidaciones firmes) en el plazo de prescripción de 4 años computados desde la fecha en que se realizó el ingreso y no desde la fecha de la sentencia que declaró la infracción del derecho europeo (76), sin que el hecho de estar sub iudice el examen de la validez de la norma implique, de facto, una suspensión de los plazos para instar la devolución o recurrir, en su caso, la liquidación.

Ahora bien, a mi juicio, como he apuntado en otra ocasión, desde el punto de vista del derecho a la tutela judicial efectiva, que implica una equivalencia de sistemas y cauces de revisión cuando la causa material del ingreso indebido es la misma (invalidez de la norma), debieran equipararse las posibilidades de recuperar lo indebido con independencia de que la obligación tributaria se hubiera autoliquidado o hubiera sido objeto de una liquidación administrativa (77). Es cierto, como ya se señaló anteriormente, que el TC ha inadmitido una cuestión de inconstitucionalidad por este motivo (ATC 116/2019, de 15 de octubre) con relación a las plusvalías "liquidadas" frente a las "autoliquidadas", pero nada impediría, a mi juicio, que o bien el órgano jurisdiccional que declarase la invalidez de la norma habilitara en su fallo la equiparación entre liquidaciones y autoliquidaciones o bien pudiera instarse la rectificación de la autoliquidación o, en su caso, de la declaración que ha servido de base para una liquidación firme aduciendo, como "motivo distinto" el referido a la invalidez de la norma de cobertura. De este modo, al menos, se aproximarían los plazos para obtener la devolución de ingresos indebidos de autoliquidaciones y liquidaciones cuando ambas se hubieran visto afectadas por la invalidez de la norma de cobertura. En último término, además, nada impediría una reforma de la LGT que permitiera "reponer" o "rehabilitar" los plazos de impugnación de las liquidaciones firmes o que reconociera

(74) Vid., STJUE de 28 de enero de 2010, asunto C.264/08, Belgische Staat C.Direct Parcel Distribution.

(75) Y el ejemplo más notorio y reciente han sido las consecuencias derivadas de la devolución del llamado "céntimo sanitario", a pesar del impacto económico, tras la STJUE de 27 de febrero de 2014, asunto C-82/12, Transportes Jordi Besora C. Generalitat de Catalunya. Sobre el tema, en particular, vid., Herrera Molina, (2013).

(76) Vid., entreotras, STS de 16 de noviembre de 2016, recurso 1590/2015, ECLI:ES:TS:2016:4979, que cuenta, no obstante, con tres votos particulares en los que, en síntesis, a la vista de la nueva regulación del artículo 32 de la Ley 40/2015, en aras del principio de efectividad, que fija el dies a quo para instar la reclamación de responsabilidad patrimonial del estado legislador por infracción del derecho europeo desde la publicación de la sentencia, debería haberse elevado una cuestión prejudicial.

(77) Vid., Sesma Sánchez (2017). 
expresamente como un supuesto de devolución de oficio los supuestos de invalidez de la norma a fin de incluir, sin necesidad de instar la revisión o la revocación, a los actos firmes. Un sistema análogo es el previsto, de hecho, para articular la recuperación de ayudas de estado de carácter fiscal (Título VII de la LGT) donde, al margen de la firmeza de los actos tributarios subyacentes (autoliquidaciones o liquidaciones), se arbitra un mecanismo legal que permite exigir la devolución de la ayuda de estado porque un pronunciamiento europeo así lo exige (78).

\subsection{El recurso extraordinario de revisión}

Las sentencias anulatorias de normas tributarias tampoco han merecido la calificación de "documentos de valor esencial para la decisión del asunto que fueran posteriores al acto o resolución de recurridos o de imposible aportación al tiempo de dictarse los mismos y que evidencien el error cometido» a los efectos de utilizar la vía del recurso extraordinario de revisión (art. 244 LGT). Con reiteración, tanto el TEAC como los tribunales contencioso-administrativos han entendido que por "documentos esenciales" debe tratarse de documentos referidos a hechos relevantes para la decisión que no resulten del expediente administrativo, o posteriores al acto que no hubieran podido aportarse previamente o pronunciamientos que incidan directamente sobre el presupuesto esencial de la liquidación o sobre los hechos y elementos fácticos de la obligación tributaria, quedando excluidas de esta categoría las sentencias anulatorias referidas a la norma de cobertura. Ni el TEAC (79), ni el TS (80) admiten que la jurisprudencia, los criterios jurisprudenciales o los pronunciamientos sobre normas aplicables constituyan "documentos esenciales" a los efectos de habilitar, por este cauce, una nueva oportunidad de discutir un acto firme en vía administrativa o confirmado por una resolución económico administrativa.

\section{LA RESPONSABILIDAD PATRIMONIAL DEL ESTADO LEGISLADOR O DE LA ADMINISTRACIÓN POR LA APROBACIÓN DE NORMAS INVÁLIDAS}

A título subsidiario, ante las dificultades de que prosperen las anteriores alternativas de revisión de un acto tributario dictado al amparo de una norma inválida, cabe el ejercicio de una acción de responsabilidad patrimonial dirigida contra el Estado legislador, en el caso de infracciones de inconstitucionalidad y de derecho europeo o contra la Administración, en el caso de la anulación de disposiciones generales.

(78) Vid., Pérez Bernabéu (2013) y Moreno González (2015).

(79) Entre otras muchas, Res. TEAC de 10 de octubre de 2006, 11 de septiembre de 2014 y de 13 de diciembre de 2019.

(80) Vid., entre otras, STS de 19 de mayo de 2020, rec.1571/2018, ECLI:ES:TS:2020:1031. Y referida a la imposibilidad de esgrimir una STJUE a estos efectos, STS de 27 de diciembre de 2015, rec. 19/2004, ECLI:ES:TS:2005:7837. 
Como es sabido, la responsabilidad patrimonial del Estado legislador por normas tributarias inconstitucionales tuvo un origen y reconocimiento marcadamente jurisprudencial -no exenta de controversias doctrinales y jurisprudenciales, como lo prueban los once votos particulares a la STS de 2 de junio de 2010, rec. 588/2008, ECLI:ES:TS:2010:3898- hasta que finalmente la Ley 40/2015 la ha reconocido «muy a la baja» en su artículo 32 junto a los supuestos de infracciones de derecho europeo. Sin ánimo de examinar ahora con detalle esta regulación (81), interesa destacar que este precepto acoge dos supuestos de responsabilidad patrimonial del Estado legislador. De un lado, con carácter general, cuando se trate de la aplicación de actos legislativos de naturaleza no expropiatoria de derechos que los ciudadanos no tengan el deber jurídico de soportar y así venga establecido en los propios actos legislativos y en los términos que en ellos se especifiquen. Así, en nuestro ámbito, este podría ser el supuesto referido a la aprobación de una ley fiscal que recortara o suprimiera un beneficio fiscal pero que estableciera un régimen transitorio, indefinido o limitado, a modo de compensación de los daños provocados por la aprobación de la nueva normativa (82).

De otro lado, también se contempla la responsabilidad patrimonial del Estado legislador cuando se trata de la aplicación de una norma con rango de ley declarada inconstitucional o cuando se trate de una norma (no necesariamente una Ley) contraria al Derecho de la Unión Europea, en cuyo caso, amén de probar y acreditar el daño efectivo, es necesario que concurran ciertos requisitos:

(1) Que el particular debe haber impugnado jurisdiccionalmente el acto administrativo de aplicación de la ley inválida, lo cual ha sido cuestionado desde la perspectiva del principio de igualdad porque esta exigencia solo "premia" al recurrente y deja indefenso al contribuyente "confiado" que presumió la constitucionalidad o europeidad de la norma tributaria y no la cuestionó (83).

(2) Que en esa impugnación debe haberse alegado la invalidez (inconstitucionalidad o contravención del derecho europeo), requisito que no se está interpretando de forma estricta admitiéndose, por ejemplo, en los casos relativos a la plusvalía, que se hubiera invocado la infracción del principio de capacidad económica o la prohibición de confiscatoriedad del artículo $31 \mathrm{CE}$ aunque no hubieran sido éstos los motivos de su inconstitucionalidad (84).

(81) Vid., entre otros, García de Enterría (2005), Cobreros Mendazona (2015) y Moreno Fernández (2009). Con más detalle de doctrina y jurisprudencia he analizado esta figura en Sesma Sánchez (2017).

(82) Con relación a este supuesto baste apuntar que el TS ha señalado que el título de imputación en este caso no lo constituye la mera aprobación o aplicación de la Ley sino el hecho de que la propia norma establece la previsión de un resarcimiento por el daño que ocasione su aplicación siendo difícil, a priori, determinar cuándo debe prever el Legislador la correspondiente indemnización como contraprestación del daño que genera su aprobación, cfr. STS de 13 de julio de 2020, rec. 121/2019, ECLI:ES:TS:2020:2387.

(83) A estos efectos el TS ha señalado que haber instado la revisión de oficio sirve para acreditar el cumplimiento del requisito de haber impugnado el acto que exige el art. 32 LRJSP, vid., STS de 21 de septiembre de 2020, rec. 2820/2019, ECLI:ES:TS:2020:2917.

(84) Vid., STS de 17 de enero de 2020, rec. 71/2019, ECLI:ES:TS:2020:149. 
(3) Que debe haber recaído sentencia firme desestimatoria de cualquier instancia.

(4) La reclamación solamente puede instarse respecto de daños producidos en el plazo de 5 años anteriores a la publicación de la sentencia que declare la inconstitucionalidad, plazo que debe computarse según el TS desde la sentencia firme desestimatoria de un recurso, en cualquier instancia, contra la actuación administrativa que ocasionó el daño con independencia de cuando se hubieran ingresado las liquidaciones tributarias afectadas por la norma posteriormente invalidada (85).

Adicionalmente, tratándose de infracciones de derecho europeo, se exigen los requisitos para apreciar la responsabilidad de los estados miembros según la jurisprudencia del TJUE (en particular, que se trate de una "violación suficientemente caracterizada"), requisitos todos ellos contenidos en el citado artículo 32 LRSJP y que han sido cuestionados por la Comisión Europea hasta el punto de presentar un recurso por incumplimiento contra nuestro país por supuesta contravención de los principios de equivalencia y efectividad por exigir la impugnación del acto invocando la infracción de derecho europeo y, además, una sentencia firme desestimatoria (86).

Ciertamente, la vía de la responsabilidad patrimonial del Legislador -en muchas ocasiones compartida, a mi juicio, con la de la Administración de justicia en tanto que los órganos jurisdiccionales pueden haber descartado improcedentemente otros sistemas de revisión, incluido el planteamiento de cuestiones prejudiciales- puede operar como mecanismo subsidiario de resarcimiento en casos en los que el contribuyente, habiendo reaccionado frente a la posible invalidez de la norma, no ha tenido éxito en sus pretensiones. Ahora bien, este cauce debe supeditarse, en todo caso, al contenido material y temporal de la sentencia anulatoria, debiendo descartarse su utilización cuando el propio pronunciamiento (constitucional o europeo) ha determinado el alcance temporal o material de su fallo anulatorio. En todo caso, dada la multitud de requisitos (temporales, materiales y procedimentales) exigidos para imputar responsabilidad patrimonial al Estado legislador, tampoco esta vía arroja muchas expectativas de éxito para recuperar lo pagado al amparo de una norma inconstitucional o contraria al derecho europeo (87). El propio legislador, es obvio, busca limitar su propia responsabilidad patrimonial.

Tratándose de ejercitar la responsabilidad patrimonial de la Administración por la aprobación de disposiciones generales ilegales o inválidas, opera el cauce general de la responsabilidad patrimonial de la Administración (art. 32.1 LRJSP) si bien desde la premisa según la cual «Las Administraciones Públicas, al declarar la nulidad de una disposición o acto, podrán establecer, en la misma resolución, las indemnizaciones que proceda

(85) Vid., STS de 25 de junio de 2020, rec. 3144/2019, ECLI:ES:TS:2020:2353.

(86) España ha sido denunciada ante la Comisión Europea por la regulación del artículo 32 LRJSP, iniciándose procedimiento de infracción en fecha 14-6-2017. Posteriormente, en dictamen motivado notificado a nuestro país en fecha 25-1-2018, la Comisión ha considerado que nuestra normativa incumple los principios de equivalencia y de efectividad. Al respecto vid., Iranzo Cerezo (2020) y el comentario de Martínez Capdevila (2019), http://www.blog.fder.uam.es/2019/12/20/ la-comision-europea-lleva-a-espana-ante-el-tribunal-justicia-ue-por-nuestra-regulacion-de-laresponsabilidad-patrimonial-del-estado-por-normas-contrarias-al-derecho-ue/ [consultado el día 14/10/2020].

(87) Vid., García Moreno (2020). 
reconocer a los interesados, si se dan las circunstancias previstas en los artículos 32.2 y 34.1 de la Ley de Régimen Jurídico del Sector Público sin perjuicio de que, tratándose de una disposición, subsistan los actos firmes dictados en aplicación de la misma» (art. 106.4 LPAC). Además, «En los casos en que proceda reconocer derecho a indemnización por anulación en vía administrativa o contencioso-administrativa de un acto o disposición de carácter general, el derecho a reclamar prescribirá al año de haberse notificado la resolución administrativa o la sentencia definitiva» (art. 67.1 LPAC).

La responsabilidad de la Administración por los efectos derivados de la anulación de una disposición general debe ajustarse, en consecuencia, a los requisitos generales de esta figura. A saber, que exista un daño efectivo individualizado y evaluable económicamente, un nexo causal, un daño antijurídico, ausencia de fuerza mayor y ejercicio en plazo (1 año). En estos casos cabe advertir, además, que la jurisprudencia ha acudido a la llamada "tesis del margen de tolerancia" para descartar en muchas ocasiones la responsabilidad patrimonial de la Administración si su actuación hubiera sido "razonada y razonable" (88). En aplicación de esta doctrina son muy escasos los supuestos en los que ha prosperado esta vía en el ámbito tributario (89), pero procede señalar que algún órgano jurisdiccional (el TSJ de Asturias, en particular) ha legitimado este cauce para permitir, por ejemplo la recuperación del IBI satisfecho por inmuebles urbanos cuando la anulación del plan urbanístico implicaba, de fondo, negarles tal calificación urbanística. En estos casos, el citado TSJ ha considerado que el Ayuntamiento (no la CCAA), debía indemnizar por este importe considerando que se trataba de un daño real, efectivo y antijurídico que el contribuyente no debía soportar. A juicio del este tribunal, no habiendo obtenido la demandante beneficio urbanístico ni fiscal vinculado al planeamiento, ni contraprestación por tal pago del impuesto, queda claro que de no procederse al resarcimiento con la devolución del importe abonado se produciría no solo un enriquecimiento injusto, sino un empobrecimiento injusto (90).

En todo caso, el mecanismo de la responsabilidad patrimonial (tutela secundaria) por la aprobación de una norma inválida, ya se dirija frente al Estado Legislador o frente a la Administración es subsidiario de las vías ordinarias de revisión de los actos tributarios (tutela primaria) de modo que no cabe su ejercicio cuando por las vías ordinarias de reclamación es posible la anulación del acto dictado "sin soporte legal". Esta vía secundaria de resarcimiento no implica, además, la anulación del acto dictado al amparo de una norma inválida sino que simplemente habilita la reclamación de una indemnización por los daños derivados de su aplicación lo que exige probar, en cualquier caso, la efectividad del daño, la causalidad -que es difícil de apreciar cuando el afectado ha consentido la aplicación del acto ilegal y la aprobación de la norma no encaja en un supuesto de manifiesta invalidez- y la antijuridicidad del daño, también compleja, como lo prueba la necesidad de acreditar, en el caso de infracciones de derecho europeo, que estemos ante una "violación suficientemente caracterizada".

(88) Vid., por todos, Fernández Rodríguez (2008), Domenech Pascual (2010) y Muñoz Guijosa (2012).

(89) Vid., Sesma Sánchez (2017).

(90) Vid., entre otras, la STSJ de Asturias de 27 de diciembre de 2018 (rec. 610/2017, ECLI:ES:TSJAS:2018:4077). 


\section{BIBLIOGRAFÍA}

Agoués Mendizábal, C. (2017): "La modulación de los efectos de la nulidad de los reglamentos", en VVAA, XII Congreso de la Asociación Española de Profesores de Derecho Administrativo, 361 y ss.

Alonso García, R. y Almudí Cid, J. M. (2020): "El Tribunal Supremo ante la constitucionalidad y la europeidad de las Leyes", Revista de Administración Pública, n 212: 55 y ss.

Baño León, J. M. (2019): "La competencia jurisdiccional para concretar los efectos de la anulación de Reglamentos y planes", Revista de Administración Pública, nº 210:43 y ss.

Calderón González, J. M., y Ordóñez Solís, D. (2016): “Anulación e indemnización en el derecho tributario español de actos firmes contrarios al derecho de la Unión Europea", Revista Aranzadi Unión Europea, nº 2:31 y ss.

Cano Campos, T. (2014): "La invalidez sobrevenida de los actos administrativos", Civitas, Madrid.

Cano Campos (2017): "El laberinto de la invalidez: algunas pistas para no perderse", Revista InDret, 4.

Cobreros Mendazona, E. (2015): Responsabilidad patrimonial del Estado por incumplimiento del derecho de la Unión Europea, Iustel, Madrid.

Cobreros Mendazona, E. (2016): "Efectos temporales de las sentencias prejudiciales de interpretación del Tribunal de Justicia de la Unión Europea", Revista Vasca de Administración Pública, $\mathrm{n}^{\circ}$ 105: 67 y ss.

Cobreros Mendazona, E. (2018): "El diálogo judicial para la construcción de la responsabilidad patrimonial del Estado por leyes contrarias al Derecho de la Unión Europea", $A F D U A M, \mathrm{n}^{\circ} 22: 421$ y ss.

Collado Martínez, R. M. (2018): "La revocación de los actos administrativos en la doctrina legal del Consejo de Estado", Revista Española de Derecho Administrativo, n $195: 221$ y ss.

Cunillera i Busquets, M. (2004): "La extensión de sentencias y la invalidez de los actos dictados al amparo de ordenanza fiscal nula”, Tributos Locales, n 46: 117 y ss.

Domenech Pascual, G. (2002): La invalidez de los reglamentos, Tirant lo Blanch, Valencia.

Domenech Pascual, G. (2010): "Responsabilidad patrimonial de la Administración por actos jurídico ilegales ¿Responsabilidad objetiva o por culpa?”, Revista de Administración Pública, nº 183: 187 y ss.

Eseverri González, E. (2018); La devolución de ingresos indebidos, Tirant lo Blanch, Valencia.

Fernández Rodríguez, T. (2008): De la arbitrariedad de la Administración, Civitas, Madrid.

Fuentetaja Pastor, J. (2018): "Equivalencia y efectividad en la revisión de los actos administrativos nacionales contrarios al derecho europeo", Documentación Administrativa, $\mathrm{n}^{\circ} 5$.

García de Enterría, E. (2005): La responsabilidad patrimonial del Estado legislador, Civitas, Madrid.

García Moreno, V. A. (2020): "Responsabilidad patrimonial del Estado legislador. Una solución para muy pocos contribuyentes que recurrieron y no vieron satisfecha su pretensión”, Carta Tributaria, $\mathrm{n}^{0} 59$. 
García Moreno, V. A. (2020): "La vulneración del Derecho comunitario sí que puede ser causa de nulidad de liquidaciones consentidas y firmes", Carta Tributaria, n ${ }^{\circ} 68$.

García Novoa, C. (2005): La revocación en la Ley General Tributaria, Thomson Aranzadi, Pamplona.

González Sanfiel, A. M. (2018): "Nulidad del planeamiento urbanístico e invalidez de los actos amparados en el mismo. Atención especial a las nuevas iniciativas legislativas al respecto", Documentación Administrativa, $\mathrm{n}^{\circ}$ 5: 47 y ss.

González-Varas Ibáñez, S. (2009): "Los efectos de las sentencias anulatorias de los tribunales constitucionales", Revista de Administración Pública, nº 178: 361 y ss.

Guichot Reina, E. (2016): "La responsabilidad del Estado Legislador por infracción del Derecho de la Unión Europea en la jurisprudencia y en la legislación española a la luz de los principios de equivalencia y efectividad", Revista Española de Derecho Europeo, $\mathrm{n}^{\circ}$ 60: 49 y ss.

Herrera Molina, P. M. (2013): “Debe devolver Hacienda 13.0000 millones de euros? Conclusiones del Abogado General Wahl en el caso TJB (Impuesto sobre las ventas minoristas de determinados hidrocarburos)", en ECJ Leading Cases.

Huergo Lora, A. (2012): "Los efectos en otros procesos de las sentencias no firmes que declaran la nulidad de un reglamento", en VVAA, Eduardo García de Enterría Martínez-Carande, Ricardo Alonso García (coords.), Administración y justicia: un análisis jurisprudencial: liber amicorum Tomás-Ramón Fernández, Vol. 1: 1463 y ss.

Iranzo Cerezo, J. M. (2020): "La dudosa compatibilidad con los principios de equivalencia y efectividad de la regulación de la responsabilidad por incumplimiento del Derecho de la Unión Europea”, Revista Española de Derecho Administrativo, nº 205.

Jimenez Campo, J. (1997): “¿Qué hacer con la Ley inconstitucional?”, en AAVV, La sentencia sobre la constitucionalidad de la Ley: actas de las II Jornadas de la Asociación de Letrados del Tribunal Constitucional.

Lopez Ramón, F. (2018): "La calificación de los vicios de los reglamentos", Revista de Administración Pública, $\mathrm{n}^{\circ}$ 5: 27 y ss.

Marín-Barnuevo Fabo, D. (2017): "Significado y alcance de la declaración de inconstitucionalidad de la regulación del IIVTNU en Guipúzcoa y Álava”, Revista de contabilidad y tributación, $\mathrm{n}^{\circ} .409$.

Marín-Barnuevo Fabo, D. (2020): "Procede la anulación inmediata de las liquidaciones del IBI cuando se anula la valoración catastral: análisis de la STS de 18 de mayo de 2020, rec. núm. 6950/2018”, Revista de contabilidad y tributación, n 451.

Martínez Lafuente, A. (2020): "La nulidad de pleno derecho en materia tributaria", Carta Tributaria, $\mathrm{n}^{\circ}$ 65-66.

Martín Queralt, J. (2019): "De los «peajes» en el camino a la tutela judicial efectiva”, Carta Tributaria, $\mathrm{n}^{\circ} 56$.

Martín Rebollo, L. (2019): "De nuevo sobre la invalidez en el derecho público, con particular referencia a la invalidez de los reglamentos (Una reflexión abierta y algunas propuestas)", Revista de Administración Pública, n² 210: 91 y ss.

Martínez Muñoz, Y. (2006): La revocación en materia tributaria, Iustel, Madrid.

Moreno Fernández, J. I. (2009): La responsabilidad patrimonial del Estado legislador, Thomson Aranzadi. 
Moreno González, S. (2015): "La recuperación de ayudas de Estado de carácter tributario: panorama actual y propuestas de futuro", Quincena Fiscal, n ${ }^{\circ} 6$.

Muñoz Guijosa, M. A. (2012): "Reflexiones en torno a la doctrina de la racionalidad y razonabilidad de la conducta administrativa en la responsabilidad patrimonial por anulación de acto administrativo", en VVAA, Administración y Justicia. Un análisis jurisprudencial, Tomo I, Liber Amicorum T. Ramón Fernández, Civitas, Madrid: 1781 y ss.

Nuñez Lozano, C. (2017): "La eficacia de las sentencias del Tribunal de Justicia de la Unión Europea sobre los Actos Nacionales", en VVAA, El alcance de la invalidez de la actuación administrativa: Actas del XII Congreso de la Asociación Española de Profesores de Derecho Administrativo, 549 y ss.

Pagés i Galtés, J. (2019): "Efectos de la declaración de inconstitucionalidad parcial del IIVTNU tras la sentencia interpretativa dictada por el Tribunal Supremo en 2018", Revista de Estudios de la Administración Autonómica y Local, $\mathrm{n}^{\circ}$ 11: 156 y ss.

Palao Taboada, C. (1995): "Nulidad de reglamentos y devolución de ingresos realizados en virtud de actos dictados en su aplicación”, Revista de Contabilidad y Tributación, $\mathrm{n}^{\circ}$ 195: 5 y ss.

Pérez Bernabéu, B. (2013): La recuperación de ayudas de Estado. Principios y procedimiento. IEF, Madrid.

Rebollo Puig, M. (2018): "Efectos de las sentencias anulatorias de reglamentos, en especial su retroactividad", Revista Andaluza de Administración Pública, nº 100: 488 y ss.

Rodríguez Márquez, J. (2004): "La invalidez de los actos dictados al amparo de una ordenanza fiscal declarada nula: interpretación del art. 19 del TRLRHL”, Aranzadi Jurisprudencia Tributaria, $\mathrm{n}^{\circ}$ 4: 28 y ss.

Ruiz Almendral, V. (2018): "Alcance y efectos de la doctrina constitucional sobre el Impuesto sobre el Incremento de Valor de los Terrenos de Naturaleza Urbana: cuestiones problemáticas", Revista de Contabilidad y Tributación, Centro de Estudios Financieros, $\mathrm{n}^{\mathrm{o}} 427$.

Ruiz Almendral, V. (2020): "Los efectos variables de las declaraciones de inconstitucionalidad de las normas tributarias y la imprevisibilidad de sus consecuencias", Nueva Fiscalidad, $\mathrm{n}^{\mathrm{O}} 2$.

Rubio Llorente, F. (1988): "La jurisdicción constitucional como forma de creación de Derecho", Revista Española de Derecho Constitucional, n $22: 9$ y ss.

Ruiz Palazuelos, N. (2019): "Anulación y poderes del juez: las enseñanzas del caso francés”, Revista de Administración Pública, n 108: 179 y ss.

Ruiz Zapatero, G. (2006): "Los efectos de las leyes tributarias inconstitucionales", Revista de Administración Pública, n 169: 99 y ss.

Santamaría Pastor, J. A. (1975): "La nulidad de pleno derecho de los actos administrativos. Contribución a una teoría de la ineficacia en el derecho público", IEA: 390 y ss.

Santamaría Pastor, J. A. (2016): "El nuevo régimen de revisión de oficio y de los recursos administrativos", Revista Vasca de Administración Pública, n ${ }^{\circ} 105: 247$ y ss.

Sesma Sánchez, B. (2017): La nulidad de las liquidaciones tributarias, Thomson Aranzadi.

Sesma Sánchez, B. (2020) "La invalidez sobrevenida del IBI: causas y alternativas de revisión”, Quincena Fiscal, n 1-2: 17 y ss. 
Toledano Cantero, R. (2018): "La responsabilidad patrimonial del Estado por infracción del Derecho de la Unión Europea por los tribunales nacionales. Estudio de la jurisprudencia del Tribunal de Justicia de la Unión Europea y aproximación a las novedades introducidas en la Ley 40/2015, de Régimen Jurídico del Sector Público”, Revista Andaluza de Administración Pública, n ${ }^{\circ}$ 100: 655 y ss.

Teso Gamella, M. P. (2019): "La impugnación de los reglamentos: los efectos de la declaración de nulidad”, Revista de Administración Pública, n 210: 69 y ss.

Triana Reyes, B. (2017): "Efectos de las sentencias del Tribunal Constitucional tras la nueva Ley del Sector Público: al hilo de la reciente anulación parcial del impuesto de plusvalías que cobran los Ayuntamientos", Diario La Ley, nº 8961, 17 de abril. 